University of Nebraska - Lincoln

DigitalCommons@University of Nebraska - Lincoln

Effective Selectors? Interlibrary Loan Patrons as Monograph

Purchasers: A Comparative Examination of Price and CirculationRelated Performance

\author{
David C. Tyler \\ University of Nebraska - Lincoln, dtyler2@unl.edu \\ Joyce C. Melvin \\ University of Nebraska-Lincoln, jmelvin1@unl.edu \\ Yang $\mathrm{Xu}$ \\ George Mason University \\ Marylou Epp \\ University of Nebraska-Lincoln, mepp1@unl.edu \\ Anita M. Kreps \\ University of Nebraska-Lincoln, akreps1@unl.edu
}

Follow this and additional works at: https://digitalcommons.unl.edu/libraryscience

Part of the Library and Information Science Commons

Tyler, David C.; Melvin, Joyce C.; Xu, Yang; Epp, Marylou; and Kreps, Anita M., "Effective Selectors? Interlibrary Loan Patrons as Monograph Purchasers: A Comparative Examination of Price and CirculationRelated Performance" (2011). Faculty Publications, UNL Libraries. 241.

https://digitalcommons.unl.edu/libraryscience/241

This Article is brought to you for free and open access by the Libraries at University of Nebraska-Lincoln at DigitalCommons@University of Nebraska - Lincoln. It has been accepted for inclusion in Faculty Publications, UNL Libraries by an authorized administrator of DigitalCommons@University of Nebraska - Lincoln. 


\title{
Effective Selectors? Interlibrary Loan Patrons as Monograph Purchasers: A Comparative Examination of Price and Circulation-Related Performance
}

\author{
David C. Tyler and Joyce C. Melvin \\ University of Nebraska - Lincoln, Lincoln, Nebraska, USA \\ Yang $\mathrm{Xu}$ \\ George Mason University, Fairfax, Virginia, USA \\ Marylou Epp and Anita M. Kreps \\ University of Nebraska - Lincoln, Lincoln, Nebraska, USA \\ Corresponding author - David C. Tyler, University of Nebraska-Lincoln, \\ 225D Love Library, P.O. Box 884100, Lincoln, NE 68588-4100, USA; email dtyler2@unl.edu
}

\begin{abstract}
In the library literature, a great deal of interest in patron-driven collection development has recently been expressed, especially in those programs that link acquisitions with interlibrary loan. However, the implementation of such programs has been limited, at least in part because of concerns over the potential for wasteful spending. The authors will attempt to address this common concern by assessing whether monies spent via a patron-driven acquisitions program were more or less effective than monies spent via traditional modes of acquisition.
\end{abstract}

Keywords: patron-driven acquisitions, purchase-on-demand, interlibrary loan, use study, monographs

\section{Introduction}

Over the past decade and more, there has been a great deal of interest expressed in the library literature in patron-driven collection development, particularly in the purchasing of books triggered by interlibrary loan (ILL) requests. The results reported in the literature for these sorts of programs have been almost universally positive, but a recently published regional study concluded that the implementation of patron-driven purchase-on-demand 
(POD) types of programs has been limited to large public universities and that the few extant programs were mostly of fairly recent vintage (Carlisle Fountain \& Frederiksen, 2010).

That study, and the wider literature, suggest that librarians have grave reservations where patrons-as-selectors are concerned. The common position seems to be that librarians and book vendors, as selectors, are guided by a broad and deep knowledge of college, department, and program needs and interests, as expressed through collection-development policies and approval plans, but that patrons have only their own narrow and ephemeral needs in mind (Kuhn, 2004; Price \& McDonald, 2009; Rottmann, 1991; Tyler, Xu, Melvin, Epp, \& Kreps, 2010). Unfortunately, to add fuel to this anti-patron prejudice, there is also evidence in the library literature that ILL patrons often fail to assess the adequacy of their libraries' holdings prior to initiating requests (Bombeld \& Hanerfeld, 2004; Houle, 2003, 2004; Ingold, 2004; Jackson, 1989). Finally, there is a sense expressed in the literature that patrons, as selectors/purchasers, are unaware of or less influenced by book prices than are budget-bound librarians, and so there is a fear that patrons will be less cautious in their spending (Levine-Clark, 2010; Reynolds et al., 2010). In essence, librarians contemplating the adoption of a POD program seem to fear that allowing patrons to add books to the collection will result in a library larded with expensive materials that do not fit the library's collection priorities, are of narrow interest, and see relatively little use (Comer \& Lorenzen, 2006).

To address some of these spending- and use-related concerns, the authors will assess some of the outcomes of the first 5 years of the on-going patron-initiated ILL book POD program at the University of Nebraska-Lincoln (UNL). The authors will first compare the average prices paid for books acquired via the UNL University Libraries' various avenues for selection (i.e., book vendors via the Approval Plan, librarians via Librarian Firm Order, donors via targeted Donor Bequest, and patrons via ILL POD). Second, the authors will determine the amount spent via each selector avenue on uncirculated, or "idle," books. Third, the authors will attempt to assess the average relative use-value of these books by examining the relationships between the average amounts spent on the books and the summed average annual rates of circulation that these books represent.

\section{Literature Review}

A review of the recent literature should put many, if not all, of librarians' concerns over POD to rest. The belief that POD books experience relatively low levels of use, for example, appears to have been well refuted. The numerous usage studies that the authors were able to locate, most of which focused specifically on ILL POD, reported that POD items circulated or were otherwise used more frequently than items acquired through traditional channels, 
experienced comparatively higher amounts of multiple use, or both (Anderson et al., 2002; Bombeld \& Hanerfeld, 2004; Brug \& MacWaters, 2004; Campbell, 2006; Gibson \& Kirkwood, 2009; Hodges, Preston, \& Hamilton, 2010; Houle, 2003, 2004; Hussong-Christian \& Goergen-Doll, 2010a; Nixon \& Saunders, 2010; Perdue \& Van Fleet, 1999; Reynolds et al., 2010; Stowell Bracke, 2010; Tyler et al., 2010; Ward, 2002; Ward, Wray, \& Debus- López, 2003; Way, 2009; Zopfi-Jordan, 2008). In fact, one recent study even reported that ILL POD books maintained a significant circulation advantage over traditionally acquired books a decade after their having been added to the collection, even when the initial circulation to the requesting ILL patron was controlled for (Nixon \& Saunders, 2010).

The overall suitability of POD books for the library collection also seems, from the literature, to have been equally non-problematic. Although there has been some slight evidence that topically inappropriate books and not collected material types have been purchased via POD, (Chan, 2004; Gee \& Shirkey, 2010; Hussong-Christian \& Goergen-Doll, 2010a; Stowell Bracke, 2010), in the main, librarians reviewing the requested and/or purchased POD items have found them to be worthy of purchase (Allen, Ward, Wray, \& DebusLópez, 2003; Anderson et al., 2002; Anderson et al., 2010; Cornell University Library, 2007; Gee \& Shirkey, 2010; Ruppel, 2006; Stowell Bracke, 2010; Ward et al., 2003; Zopfi-Jordan, 2008). Librarians reviewing POD acquisitions at a greater remove have found that POD books were purchased primarily for collection-appropriate subject classifications (Chan, 2004), for subject classifications that experienced locally higher-than-average levels of use (Tyler et al., 2010), or had also been purchased by peer institutions (Way, 2009). Not surprisingly, most patrons reviewing their selections after receipt have found the POD books to be useful and/or worthwhile additions to their libraries' collections (Foss, 2007; Hussong-Christian \& Goergen-Doll, 2010a, 2010b; Ward, 2002;). Of course, most POD programs have criteria in place to ensure that purchased items meet their libraries' standards (Carlisle Fountain \& Frederiksen, 2010), so results reported in the literature are not indicative of what might happen were patrons left entirely to their own devices. They do suggest, though, that, with some brief guidelines in place (see Appendix $C$ for an example), patrons did very well at selecting collection-appropriate books of comparatively wide interest (Hussong-Christian \& Goergen-Doll 2010b; Tyler et al. 2010; Way 2009).

Unfortunately, the evidence in the library literature regarding librarians' concerns over patron-selectors' spending has been somewhat mixed. While most studies reported that POD book prices were not excessive, some studies did note that these prices were somewhat higher than the costs associated with the borrowing of ILL returnables (Bombeld \& Hanerfeld, 2004; Campbell, 2006; Chan, 2004; Ward, 2002; Ward et al., 2003). A few studies reported that ILL POD books may cost slightly more on average than traditionally ac- 
quired books (Houle, 2003, 2004; Perdue \& Van Fleet, 1999; Tyler et al., 2010). Two studies of unusual ILL POD programs (one with overseas shipping and one with direct delivery to the requesting patron) have reported high shippingand-handling fees (Bertuca et al., 2009; Chan, 2004;). Not all unusual POD programs reported higher costs, however: one study of a program devoted solely to the POD purchase of a society's proceedings noted that overall costs were considerably less than subscribing to the proceedings or paying the cumulative ILL and copyright fees (Gibson \& Kirkwood, 2009). With respect to programs' overall costs, one program study noted that the budget for its pilot test had to be doubled (Bombeld \& Hanerfeld, 2004), and another reported that its budget had to be tripled (from $\$ 5,000$ to $\$ 15,000$ ) over a 4-year interval (Gee \& Shirkey, 2010). On the other hand, a study of another program reported that a sizeable percentage of librarians said that their initial fears of overspending had proven to be unwarranted (Reynolds et al., 2010). On the whole, it seems that POD programs have been successful in adding high-use and collection-appropriate materials to their libraries' collections. Material costs and program budgets, however, warrant further examination.

\section{Background}

The University of Nebraska-Lincoln (UNL) began its ILL POD program at the beginning of the 2003/04 fiscal year. At the time that the authors reviewed the program (December 2008), it had been in operation for 5.5 fiscal years. Over this period, UNL enrolled an average of 22,221 students, of which an average of 4,731 were in graduate and professional programs, and employed an average of 1,954 faculty members (University of Nebraska-Lincoln, 2005-2009). The UNL University Libraries system, comprised of the Don L. Love Memorial Library, the Marvin and Virginia Schmid Law Library, six branch libraries, and a remote storage facility, housed slightly more than three million print volumes and maintained about 39,000 current serial subscriptions (University of Nebraska-Lincoln Libraries, 2009a) ${ }^{1}$ During the interval under review (2003/20042007/2008), the UNL University Libraries' ILL department handled an average of 50,902 transactions (borrowing and lending combined) per year (2009b). The ILL department's services were available to UNL students, faculty, and staff, as well as to the state's residents for a fee.

\section{The Dataset}

Before establishing the ILL POD program, the UNL Libraries purchased books for the circulating collection primarily through one of four means: book vendor approval plans, librarian firm orders, targeted donor bequests, and a 
lost book replacement fund. The ILL POD program added a fifth option. To assess the effectiveness of these various means of selection, at the end of December 2008, the authors compiled a list of all books available for circulation that had been added to the collection while the ILL POD program was in operation. For the purposes of this study, the authors decided to exclude books purchased by the lost book replacement fund because it proved impossible to determine which means of selection had been responsible for the initial copy's purchase, and because the bulk of the books purchased via the fund were of manifestly different character than the books purchased via other means (e.g., they were often not recently published). From a potential pool of 69,941 circulatable books purchased during the five-and-a-half year interval, across $256 \mathrm{Li}$ brary of Congress (LC) subclasses, the authors had 68,857 books available for analysis. ${ }^{2}$ In order to better compare like with like where relative performance is concerned, the authors reduced the dataset to only those books purchased in LC subclasses that had ILL POD purchases (65,388 books in 140 subclasses). ${ }^{3}$ Table 1 offers additional information on the general characteristics of the UNL Libraries' acquisitions.

With respect to the dataset and the analysis to follow, the reader should keep in mind that, as is usually the case with secondary analysis of data, there is a certain amount of "noise" in the data. With this particular dataset, there are two particular noise effects to keep in mind: false circulations and possible confounding location effects. With respect to the former and to the ILL POD books, the authors estimate, based upon later recorded rates of non-circulation, that roughly 30-33 books purchased during the first 3 years of the program may have been credited with a false circulation because the ILL POD books were credited with a checkout upon receipt during the program's early years. With respect to the rest of the dataset, the authors estimate that 100-131 musical scores in LC subclass $\mathrm{M}$ were credited with a false checkout because they were circulated to the bindery prior to being sent to the music library. It is further estimated that 1,400-1,800 approval plan and librarian firm ordered mathematics and computer science books (LC subclass QA) may have been credited with a false checkout because they were circulated internally to a new books review shelf. With respect to location effects, the authors were hampered because the original purpose for which the dataset was compiled did not include book location as a variable of interest, so the dataset likely masks some location effects for some LC subclasses. This masking is not problematic for certain LC subclasses (e.g., NA is housed only at the architecture library; M, ML, and MT are housed only at the music library), but it may be somewhat so for others (e.g., QA books are mostly sent to the mathematics and computer science library, but some general interest books from this subclass are housed in the main library, and a small number of books on statistics are sent to a different branch for the convenience of the Department of Statistics). The reader should keep these effects in mind. 


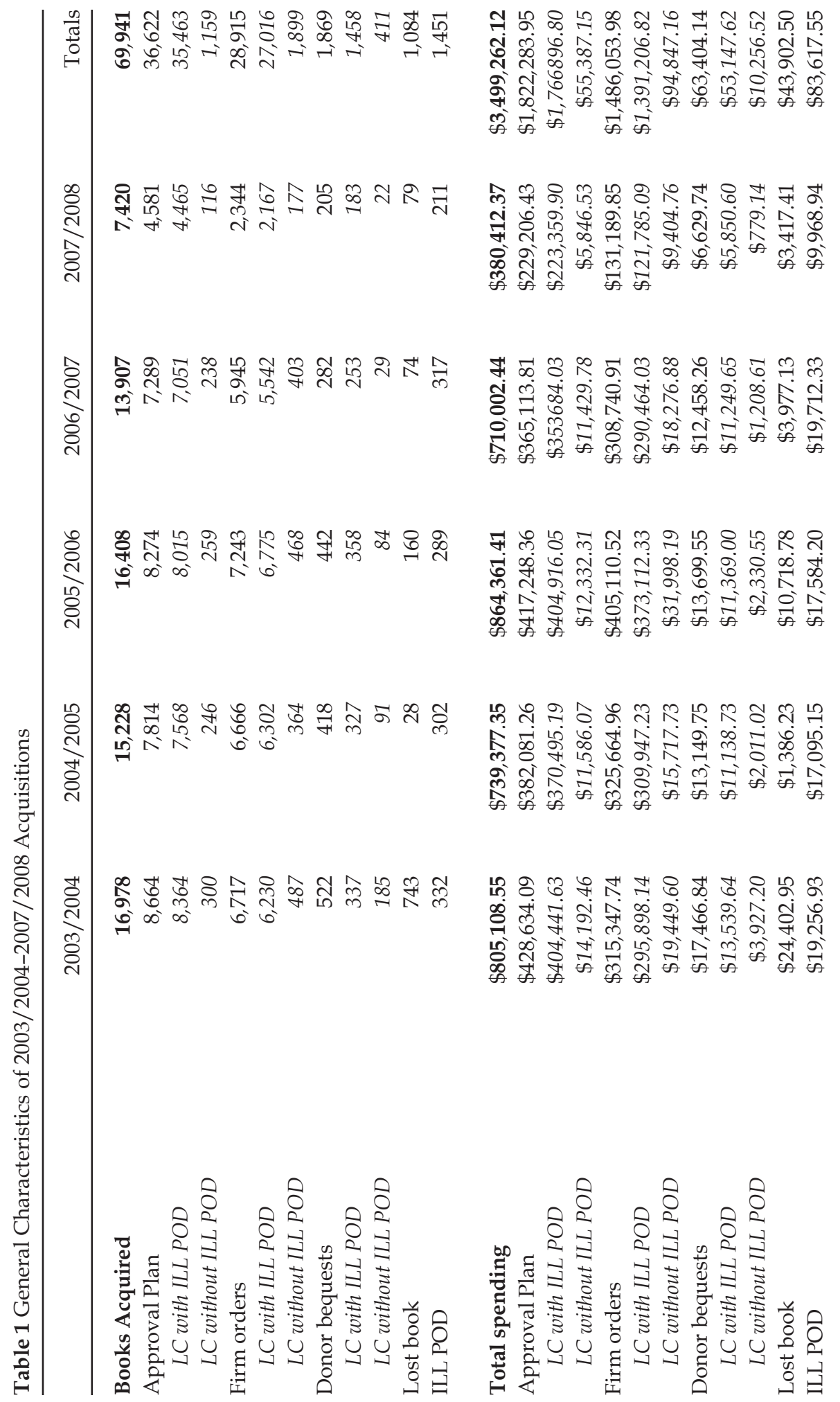




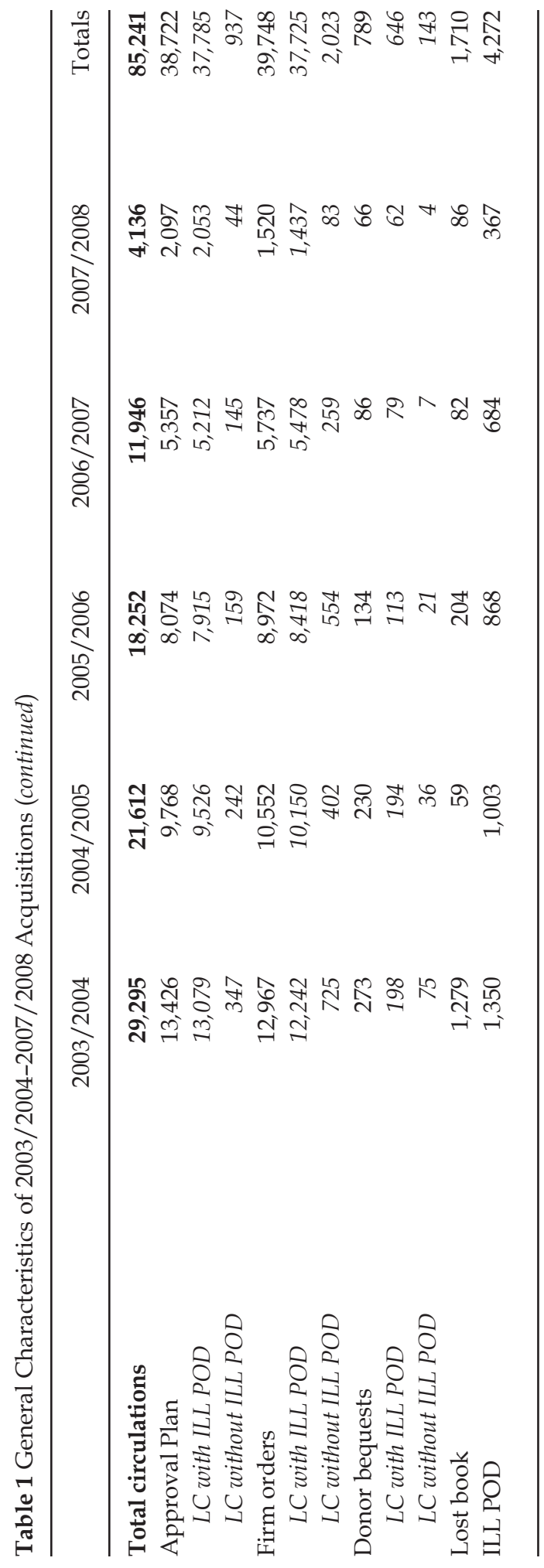


ANALYSIS OF THE DATA

Prices paid. The first question to address is whether the ILL POD books cost more, on average, than the books selected by the library's book vendors, the librarians, or library donors. Given that the ILL POD books did not receive the vendor discounts given on most of the other books, that ILL patrons did not know book prices prior to making their requests, and that ILL patrons were not spending their own money, it does seem possible that ILL POD patrons purchase more expensive books. A quick calculation of the average prices paid for the books purchased by the various book-ordering modes suggests that the ILL POD books did cost slightly more: Approval Plan $=\$ 49.76 /$ book; Librarian Firm Orders = \$51.39/book; Donor Bequest $=\$ 33.92$; and ILL POD $=\$ 57.63$. Of course, this is hardly conclusive. Any librarian would be quick to point out that book price is closely tied to discipline, topic, or even LC subclass (Houle, 2003, 2004; Foss, 2007). So, to better compare the prices paid for the books, the authors disaggregated the titles into LC subclasses and then compared the average prices paid in the 140 LC subclasses that had experienced ILL POD purchases. For purposes of comparison, Approval Plan books had 137 LC subclasses in common with ILL POD, Librarian Firm Orders had 135 LC subclasses in common, and Donor Bequest had 79 LC subclasses in common. Three of the LC subclasses had only ILL POD orders, so no comparisons were possible for these.

When ILL POD average prices paid per book were compared to the Approval Plan books, the Approval Plan books had lower average prices in 89 of the 137 LC subclasses in question, with the differences in average price ranging from just $\$ 0.12$ to $\$ 136.69$. The ILL POD books had lower average prices in 48 of the LC subclasses, with differences ranging from just $\$ 0.15$ to $\$ 68.77$. Before coming to a conclusion, however, the authors noted that in 64 of the LC subclasses in question, ILL POD patrons had requested less than one book per year, which leaves these subclasses particularly susceptible to the effect of a single unusually priced book. In the LC subclasses with more substantial ILL POD purchasing (ranging from five to 56 books), the differences in average price were much more modest. Approval Plan books cost less, on average, in 54 LC subclasses, with differences in average price ranging from $\$ 0.12$ to $\$ 52.48$. ILL POD books cost less in the remaining 19 LC subclasses, with differences in average price ranging from $\$ 0.15$ to $\$ 19.15$. Interestingly, when the authors grouped LC subclasses with substantial ILL POD purchasing by general topical area, only a handful of the science and technology subclasses (QC, QD, TA, $\mathrm{TK}, \mathrm{TP})$ and a single business subclass (HG) from the social sciences category had ILL POD prices, on average, that were at least $\$ 30.00$ more expensive than Approval Plan books. Price differences in the arts and humanities, in the rest of social sciences, and in general literature were more modest. (Note: For the categories and general topical groupings of LC subclasses employed in this study, please see Appendix A.) 
When the average prices paid per ILL POD book were compared to Librarian Firm Order books, the firm-ordered books had lower average prices in 69 of the 135 LC subclasses in question, with differences ranging from $\$ 0.38$ to $\$ 134.93$. The ILL POD books had lower average prices in 66 of the LC subclasses, with differences ranging from $\$ 0.32$ to $\$ 80.00$. Once again, however, it was noted that in 62 of the LC subclasses in question, the ILL POD patrons had requested less than one book per year. In LC subclasses with more substantial ILL POD purchasing, again ranging from five to 56 books, the differences in average price paid were, again, much more modest, with firm-ordered books costing less, on average, in 35 subclasses (range $=\$ 0.62$ to $\$ 57.14$ ), and with ILL POD books costing less, on average, in 38 subclasses (range $=\$ 0.63$ to $\$ 54.88$ ). Grouping the LC subclasses with substantial ILL POD purchasing by general topical area demonstrated that just two science and technology subclasses (repeat culprits QC and TK) and one arts and humanities subclass (PN) had ILL POD books with average prices $\$ 30.00$ or more higher than their Librarian Firm Order counterparts. Two science and technology subclasses and two arts and humanities subclasses (QD, QP, BM, BS) had average ILL POD prices that were $\$ 30.00$ lower than their firm-ordered counterparts. In fact, the average price for ILL POD books in the two religious studies subclasses was slightly greater than $\$ 50.00$ lower than firm-ordered titles in the same subclasses.

Last, when the ILL POD books' average prices paid per book were compared to the Donor Bequest books, the books purchased with donated funds were less expensive, on average, in 55 of the 79 subclasses that had both types of orders (range $=\$ 1.15$ to $\$ 110.99$ ). The ILL POD books proved to be less expensive, on average, in the remaining 24 subclasses (range $=\$ 2.68$ to $\$ 214.92$ ). In both groups, there were a number of LC subclasses with less than one purchased book per year of either type of order. When the pool of compared subclasses was reduced to the 25 that had five or more purchases of both types, the differences were, once again, more modest. Donor Bequest had just two arts and humanities subclasses and one general literature subclass wherein the favorable average price differences were greater than \$30.00 (ML, PQ, Z). ILL POD had just three science and technology subclasses wherein the differences average prices paid were very favorable: $\$ 43.80(\mathrm{QR}), \$ 57.18(\mathrm{RC})$, and $\$ 107.66$ (RJ). The difference in average price paid for pediatrics titles (RJ) was especially startling.

Thus, it would seem that the suspicion expressed in the literature-that POD books cost a bit more-does appear to be largely true for the UNL Libraries' ILL POD program. In most LC subclasses, however, the differences in average price were small, and the authors would suggest that the price paid for ILL POD books should not be an area of grave concern. In fact, as far as excessive spending is concerned, the library should perhaps be more concerned with the librarians. Of the 555 books purchased during the interval that cost more than $\$ 200.00$, ILL POD patrons purchased just 13 of them $(\$ 2,927.87$ spent; price 
range $=\$ 201.44$ to $\$ 284.05)$; the Approval Plan sent just 40 of them $(\$ 9,401.08$ spent; price range $=\$ 201.12$ to $\$ 373.16)$; but the librarians ordered 490 of them $(\$ 138,087.09$ spent; price range $=\$ 200.00$ to $\$ 839.27)$. The authors are not inclined to debate the merits of these purchases, but they do seem to suggest that a penchant for extravagant spending on books seems to reside more with librarians than with ILL POD patrons.

Idle books and idle spending. These findings might incline libraries to eschew implementing an ILL POD program, especially in the current budgetary climate (after all, who would want to pay even a little more for books with budgets as tight as they are?), but as Cohen noted in the famous University of Pittsburgh study on the use of library materials, data on usage becomes "most meaningful when combined with cost data" (1979, p. 105). With respect to the above, the authors would contend that the converse should also be true: Money saved on books with lower prices is money wasted if those books do not get used (Ward, 2002). When book prices were combined with circulation data in this study, the Approval Plan, Librarian Firm Order, and Donor Bequest books began to look like much less of a bargain. A quick review of the circulation statistics showed that, at the time the data were collected, sizeable percentages of these supposedly less expensive books had been sitting uncirculated for quite some time.

Table 2 shows that, as book selectors, the librarians, the approval plan, and the donors have acquired sizeable percentages of, and spent distressing amounts on, books that have failed to circulate. Even after several years on the shelves, more than one-third of the books purchased by the libraries' two primary means of acquisition had failed to circulate, and more than two-thirds of donor bequests had failed to circulate as well. The ILL POD books, on the other hand, had largely all circulated. Of course, as noted earlier, the data on ILL POD books is not entirely accurate for the first 3 years of the program. Also, the library literature has noted that POD books are purchased as a result of an expressed need on the part of a patron rather than in anticipation of one (i.e., "just-in-time" versus "just-in-case" collecting), so the ILL POD books were almost guaranteed at least one circulation (Hodges et al., 2010; Ward, 2002;). In conversation, librarians and faculty have complained that this "stacks the deck" in favor of ILL POD books where idleness metrics are concerned, which should make the final two rows of Table 2 particularly interesting. For this portion of the table, the authors subtracted the initial circulations from the circulated ILL POD books. As a quick review of the results suggests, ILL POD, even after removing this circulation advantage, still had much lower percentages of both idle books and the dollars spent on them than did titles purchased via the approval plan, librarians, or donors, which agrees with the comparatively higher rates of multiple circulations noted in the literature review above. Thus, monies spent on ILL POD would seem, to a much greater extent than were monies spent via other channels, to be monies spent on materials that patrons will check out. 


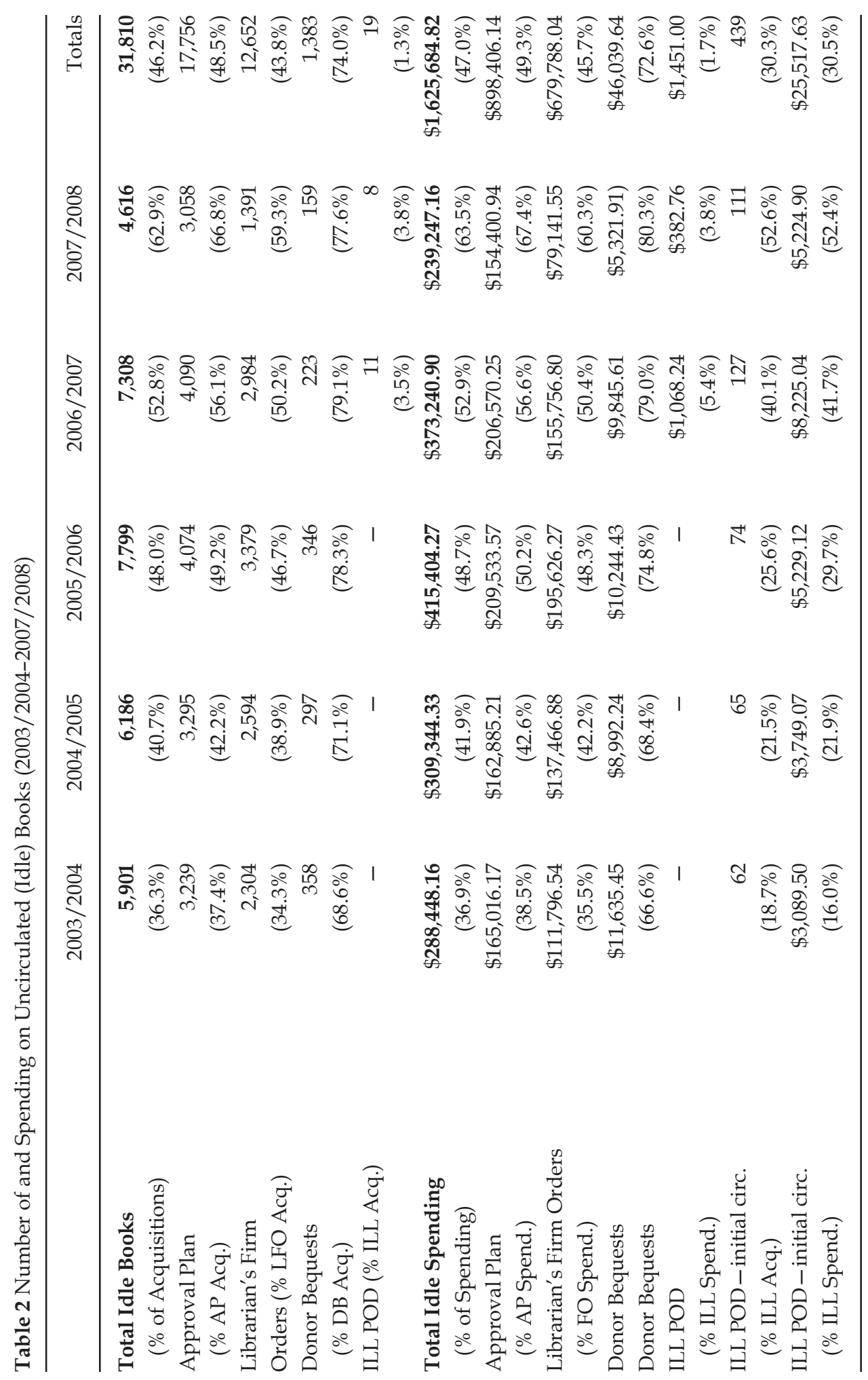


Prices paid and circulations. Beyond the questions of how much the books cost and of whether or not the books get used, the more salient question might be: how much use does one get for the dollars spent? In other words, comparatively speaking, how much bang (i.e., circulation) does one get for one's buck? If one were to ignore for the moment the question of the inherent value of books as repositories of accumulated knowledge and treat them, in a figurative sense, as if they were a kind of furnace of use, with the dollars spent representing "fuel," and circulations representing a measure of the "heat" produced, the question would then be: Which avenue of selection is the most efficient? That is, which spent the least relative to the circulation generated?

In the library literature on ILL POD, two metrics with some potential to approach this issue have been proposed: cost-per-transaction (Perdue \& Van Fleet, 1999) and the ratio of average annual turnover to the prices paid (Tyler et al., 2010). The authors also propose that a modified form of Mills' proportional use measure, Percentage Expected Use (PEU), could be usefully employed (Mills, 1982; Tyler et al., 2010). Each metric has benefits and pitfalls. The first metric is fairly simple and is easily obtained: Divide the sum of dollars spent by the total number of transactions (in this case, circulations) in order to obtain an average price paid per circulation. This metric's shortcoming, in terms of this study, is that it favors books that have had more opportunity to circulate by virtue of being on the shelf for longer periods. In a previous study, it was found that the books in this dataset had circulated at an average annual rate of 0.42 , or roughly one circulation every 2.38 years (Tyler et al., 2010), so the $70.4 \%$ of the books that have been available for checkout for 2.38 or more years, and especially the $11.3 \%$ of the books that have been available for checkout for 4.76 or more years, may enjoy something of a potential advantage with the cost-pertransaction metric.

The second metric, price paid per average annual turnover, overcomes the shortcomings of the first, but it is slightly less straightforward. To obtain the proposed ratio, one first divides the total circulations of the books by their total periods of availability to obtain an average rate of annual turnover (Baker \& Wallace, 2002), and then divides the sum spent on the books by this average rate in order to obtain a ratio of price paid to average annual turnover (Tyler et al., 2010). In essence, the metric calculates how much one would have hypothetically had to pay for a rate of one circulation per year, given that one has paid sum $X$ to obtain a book that circulated at rate $Y$. This averaging/rate-calculating process mitigates the circulation advantage of books available for longer periods. However, the metric, for this study, has its own slight disadvantage: books available for brief periods (i.e., the $6.5 \%$ of the books that had been available for less than a year) will have their rates artificially inflated through division by a fractional value.

The third, and final, metric that the authors utilized is Mills' proportional use measure Percentage Expected Use, which measures the "ratio of the per- 
centage of use of a subject to its percentage holdings" (Mills, 1982, p. 5). For this study, Mills' measure was modified in two ways. First, in order to mitigate the advantage enjoyed by books available for longer periods, the authors used average annual use, rather than total use, in the numerator. Second, in order to incorporate the costs of the books into the measure, the authors substituted sums spent for holdings in the equation's denominator. This calculates a relative use ratio of the percentage of use of a subject to its percentage of total spending. Also, to better illuminate the books' relative performance by type of selector, rather than by topic or LC subclass, the authors calculated the selectors' PEU values within topical groups (Appendix A) rather than calculating the PEU values relative to the collection as a whole. The advantage of Mills' approach is that it allows for the easy comparison of relative performance between subject areas, or between book selectors within a subject area, with different numbers of books. For example, a subject or selector that accounts for $10 \%$ of use but $5 \%$ of holdings is relatively outperforming a subject or selector that accounts for $30 \%$ of use but $20 \%$ of holdings, despite the differences in percentages seeming to favor the latter. The metric's primary drawback, in this instance, is that it may exaggerate differences in performance where there were very few books purchased. Thus, the values calculated for topics and purchase avenues where there was less than a single book purchased per year should be treated with caution.

\section{ANALYSIS By TOPIC AND SubCLASS}

General literature, biography, and LIS. This will perhaps be clearer with an example. LC subclasses were selected, in accordance with local library practice, to comprise General Literature, Biography, and Library \& Information Science (LIS), a small catch-all category (i.e., $0.6 \%$ of books acquired) for LC subclasses that do not fit neatly into the Arts \& Humanities, Social Sciences, and Sciences \& Technology categories (Appendix A). As Figure 1 shows, the ILL POD books outperformed the Approval Plan and Librarian Firm Order books in all three topical categories. (Note: The authors have elected not to include donor bequests in this discussion; since $74 \%$ of the Donor Bequest books have not yet circulated, their inclusion would merely distort the graphs.) ILL POD book performance in General Literature and in Biography should be treated cautiously, as ILL POD purchased merely three books in these categories. ILL POD acquisitions in LIS, however, could be more profitably examined, as they accounted for $6 \%$ of LIS volumes acquired and $8.5 \%$ of dollars spent in this area. The performance of all three order types in LIS was fairly good, with the average price paid per recorded circulation (Figure 1a: $\$ 37.30, \$ 38.83$, and $\$ 27.83$, respectively) less than the average price paid for the books (\$46.08), but the ILL POD average price paid per circulation was noticeably lower, despite the ILL POD 

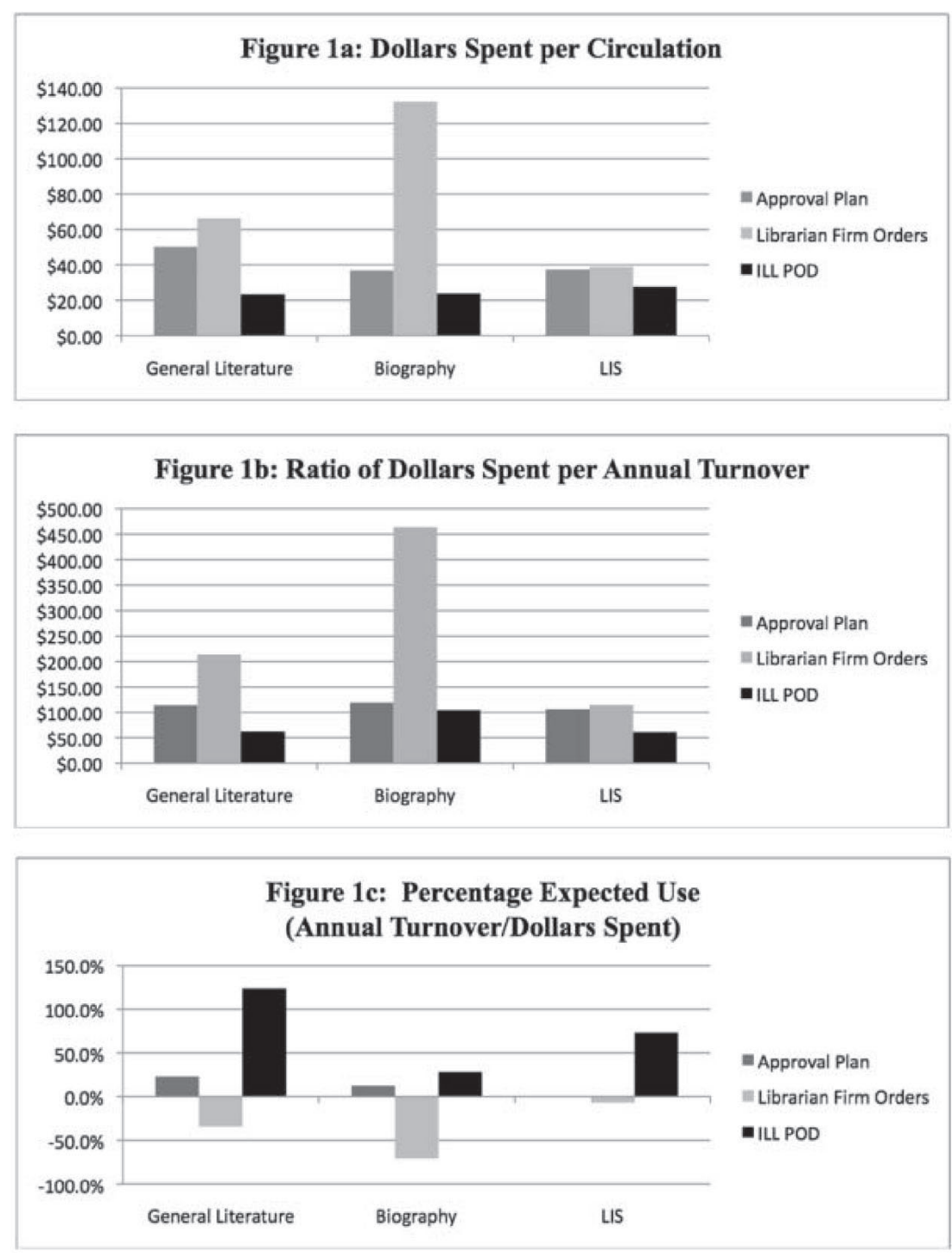

Figure 1. General Literature, Biography, and LIS.

books costing a bit more on average ( $\$ 38.70$ and $\$ 48.34$ versus $\$ 64.95$ ). This suggests that the ILL POD books had been checked out quite a bit more and had done a much better job of putting the UNL Libraries' collection dollars to work in the form of circulations. This tentative conclusion is supported by LIS's ratios of dollars spent per annual turnover. To return to our furnace metaphor, one would, as the graph in Figure $1 \mathrm{~b}$ shows, have had to pour nearly twice as much money (i.e., fuel) into the Approval Plan (\$106.63/annual circulation) and Librarian Firm Order (\$114.93) LIS books as one would have had to pour into the ILL POD books (\$61.84) to produce a rate of one circulation per 
book per year (were such a thing actually possible, of course). Lastly, with respect to proportional use, Figure 1c shows that the ILL POD contribution to LIS's annual turnover was wildly positively disproportional to the percentage of LIS dollars spent on ILL POD books, while the Approval Plan contribution was roughly proportional, and the Librarian Firm Order contribution was slightly less than proportional. (Note: The $0 \%$ line marks where the percentage contribution to average annual checkout and the percentage of spending would be perfectly proportional.) Thus, it would seem that the ILL POD books did a much more efficient job of putting the UNL Libraries' collection dollars to work, despite costing somewhat more. The desirability of this state of affairs, of course, is predicated on the assumption that the UNL Libraries' purpose in acquiring the books was that they be used by patrons (i.e., circulated), and that more use is preferable to less.

Arts and humanities. In contrast to the prior category, the books that comprise the UNL Libraries' Arts \& Humanities purchases account for nearly 45\% of books acquired and nearly 35\% of total dollars spent. Despite more substantial acquisitions and spending in this area, the authors' calculations in Figure 2 still show a similar sizeable advantage for ILL POD books. In the Philosophy LC subclasses, for example, actual circulations for traditionally acquired books were more than three times as expensive as circulations for ILL POD books (\$62.76 and $\$ 68.12$ versus $\$ 19.36 /$ circulation) and were more expensive than were the books themselves (avg. price paid $=\$ 52.89$ / book). The results for Religious Studies, as Figure 2a illustrates, were nearly as bad. In fact, the only subject in which the prices per circulation were nearly equal was Music, the topical group with the highest rate of annual circulation in the Arts \& Humanities category.

The ratios of dollars spent per annual turnover for Arts \& Humanities show a similar distribution in favor of ILL POD books. Across the board, the ratios for ILL POD books were better than those for traditionally acquired books, and in several categories the numerators of the price/annual circulation ratios were actually lower than were the average prices paid for the books. By way of contrast, the numerators for the average price per annual circulation for the approval plan and firm-ordered books ranged from 1.3 and 1.4 times the average price for the books (Music) to 3.6 times the average price (Approval Plan Philosophy) and 3.7 times the price (Librarian Firm Order Religious Studies).

The indicator that perhaps most visibly demonstrates the superior return on investment of the ILL POD purchases, however, is the PEU values. With the exception of Music, the ILL POD books' percentage contribution to their topical categories' average annual turnover was proportionally roughly $100 \%$ to $250 \%$ of the UNL Libraries' percentage spending on the ILL POD books in the same. Thus, dollars spent on ILL POD in the Arts \& Humanities would appear to have been very highly effective when compared to dollars spent via the Approval Plan and by the librarians. 

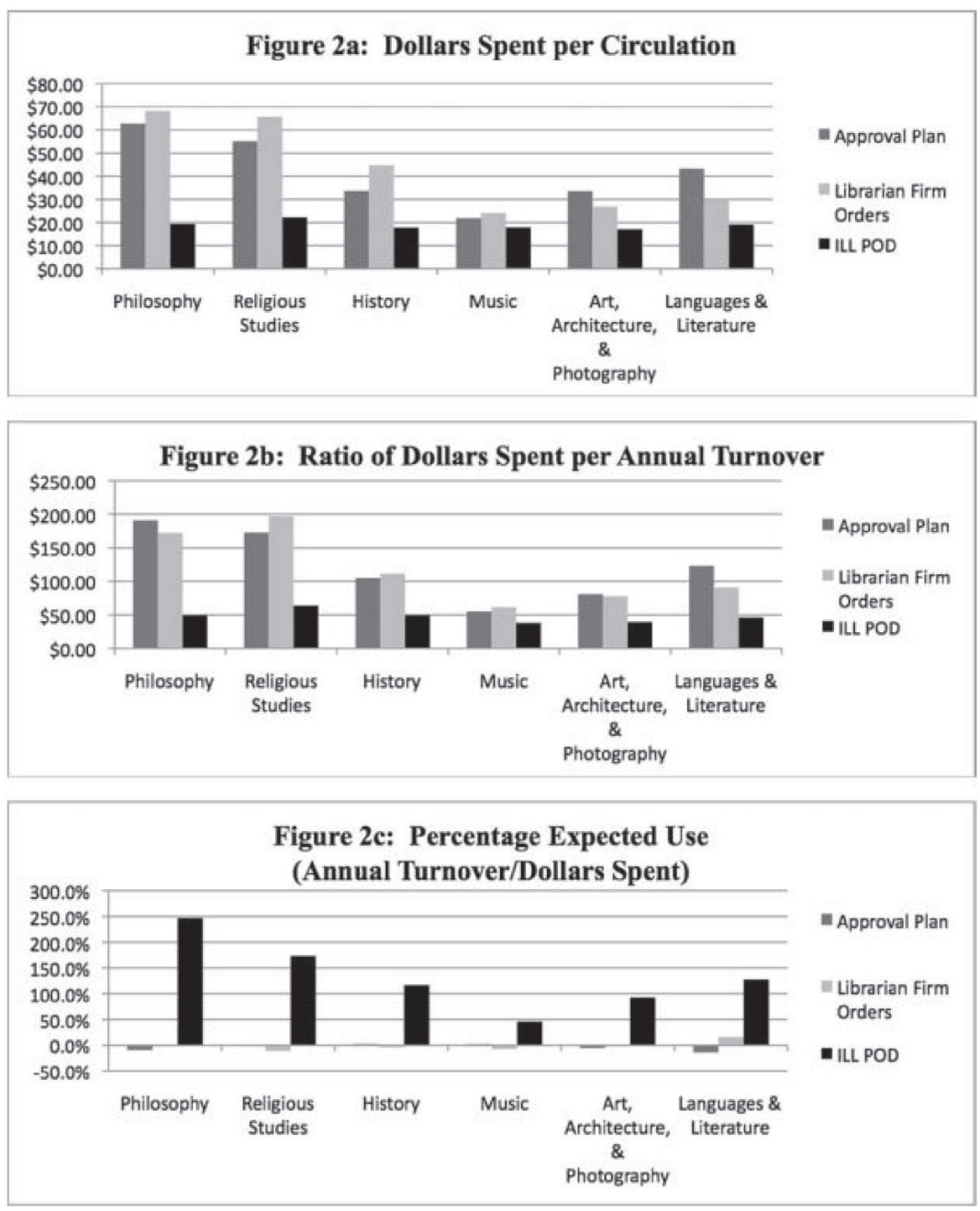

Figure 2. Arts and Humanities.

Social Sciences. The relationships between the indicators for the Approval Plan, Librarian Firm Ordered, and ILL POD books in the Social Sciences category appear to be roughly similar to those in the Arts \& Humanities (Figure 3). With the exception of Social Science \& Statistics, the several topical areas of Social Sciences show ILL POD books with an advantage. (Note: Home Economics had just one ILL POD acquisition; Military \& Naval Science had just five.) Unsurprisingly, the topical areas where some of the calculated costs per circulation and ratios of dollars spent/annual turnover were more nearly acceptablePsychology, Anthropology \& Leisure Studies, Sociology, and Education - were the topics with higher-than-average annual turnover rates for new books in Social Sciences. ${ }^{4}$ The one topical area where the indicators were nearly equal, Social Sciences \& Statistics, had one of the highest annual turnover rates for new 


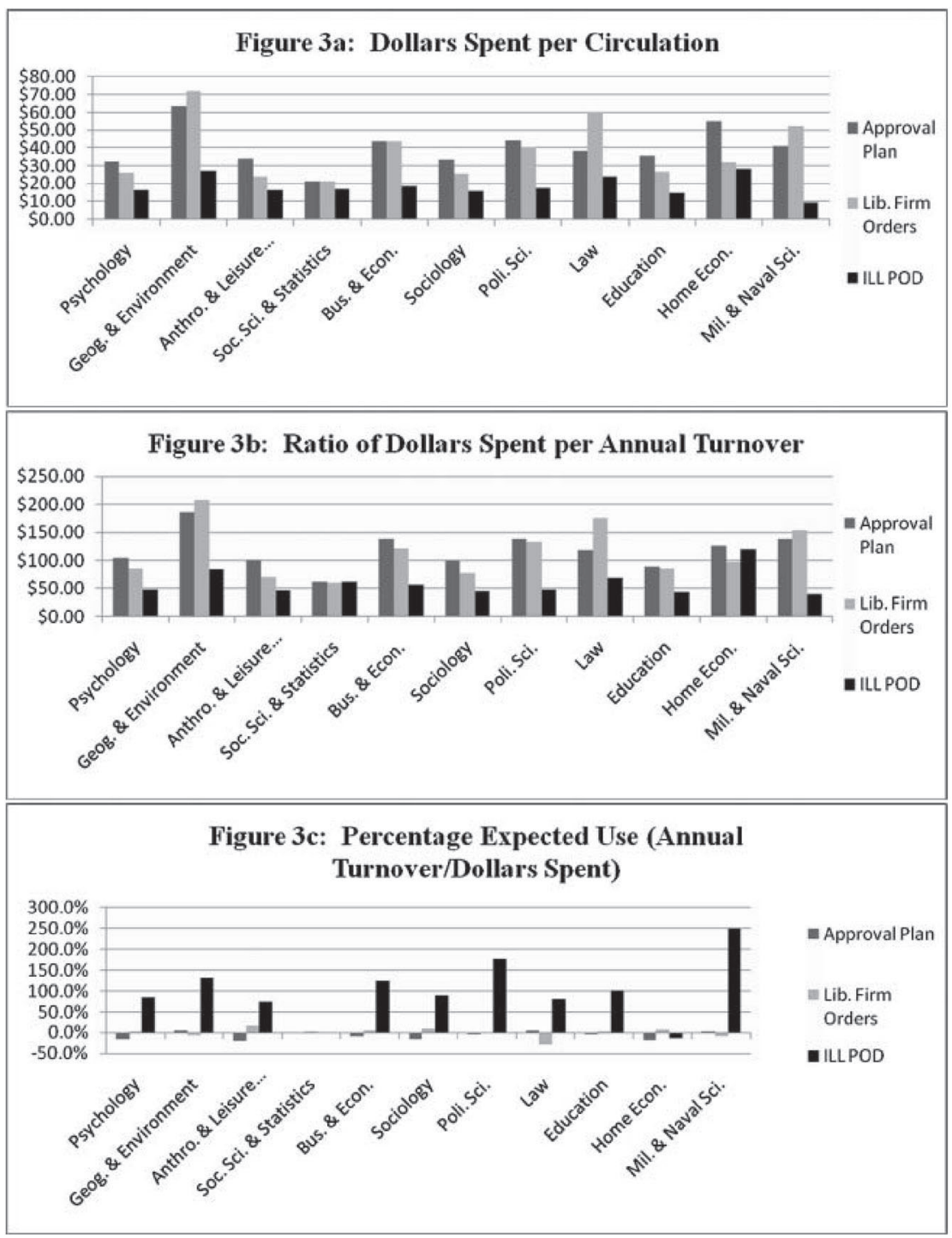

Figure 3. Social Sciences.

books not just in the Social Sciences, but in the entire collection. The remaining topical areas, where the annual turnover rates were closer to the collectionwide average for new books, showed the poorer performance more in line with that demonstrated by most of Arts \& Humanities.

As Figure 3a shows, the dollars spent per circulation for the Approval Plan, excluding Social Sciences \& Statistics, ranged from 0.7 times the average price for the books in Psychology to 1.1 times the average price for the books in Military \& Naval Sciences. For Librarian Firm Orders, these numbers ranged from 0.6 times the average price for the books in Anthropology \& Leisure Studies, 
Psychology, and Sociology to 1.4 times the average price in Military \& Naval Science. By way of contrast, the dollars spent per circulation for ILL POD books ranged from 0.2 times the average price in Military \& Naval Science to 0.5 times the average paid in Law. So, in many of the categories, ILL POD books' performance was roughly twice as good as that of traditionally acquired books. In Social Sciences \& Statistics, the remarkably bright spot in Social Sciences, the cost per circulation was slightly less than half the average price for the books for all three purchasing avenues.

As was the case in Arts \& Humanities, the differences in performance between ILL POD and the approval plan and the librarians were more exaggerated in the price per annual circulation ratios (Figure $3 b$ ). The numerators of the ratios for the ILL POD books hovered around the average price for the books in all of the groups, with a possible slight exception where Geography \& Environment (1.3 times higher) and Law (1.5 times higher) were concerned. For the Approval Plan, Social Sciences \& Statistics was the only topic group where the ratio's numerator was nearly equal to the average price for books. In the other topic groups, the numerator of the ratio ranged from 2.3 times the average price (Psychology) to 3.6 times the average price (Military \& Naval Science). The results for the librarian firm orders were roughly similar, with the Social Sciences \& Statistics numerator just slightly higher than the average price for the books in that topic and with the numerator of the ratio ranging from 1.8 times the average price (Anthropology \& Leisure Studies) to 4 times the average price (Military \& Naval Science) for the other topics.

That one would, hypothetically, have had to pump two to four times as many dollars into the books in the Approval Plan and Librarian Firm Orders columns to generate an annual turnover per book, while just paying roughly the average price of the book via ILL POD, should be enough give one pause, but, again, the clear superiority of the ILL POD books, in terms of giving a disproportionally good return on investment where circulations were concerned, showed up most clearly in the PEU calculations. As Figure 3c shows, ILL POD books provided a disproportionally high contribution to the annual turnover in every topical area but Social Sciences \& Statistics, where use was so high for all three order types that all three were roughly proportional in their contributions. In most of the topical areas that experienced substantial additions to the collection, ILL POD book PEU values were between $50 \%$ and $180 \%$, indicating that their contribution to annual turnover in the topical areas was disproportionally greater than their part of spending in the same. ILL POD book PEU value in Military \& Naval Science was a remarkable $250 \%$ above parity, but the number of ILL POD books purchased in that area might be too few to allow for solid conclusions. Regardless, ILL POD would seem, again, to have outperformed the approval plan and the librarians as a selection avenue as far as getting use value for the UNL Libraries' collection dollars is concerned. 


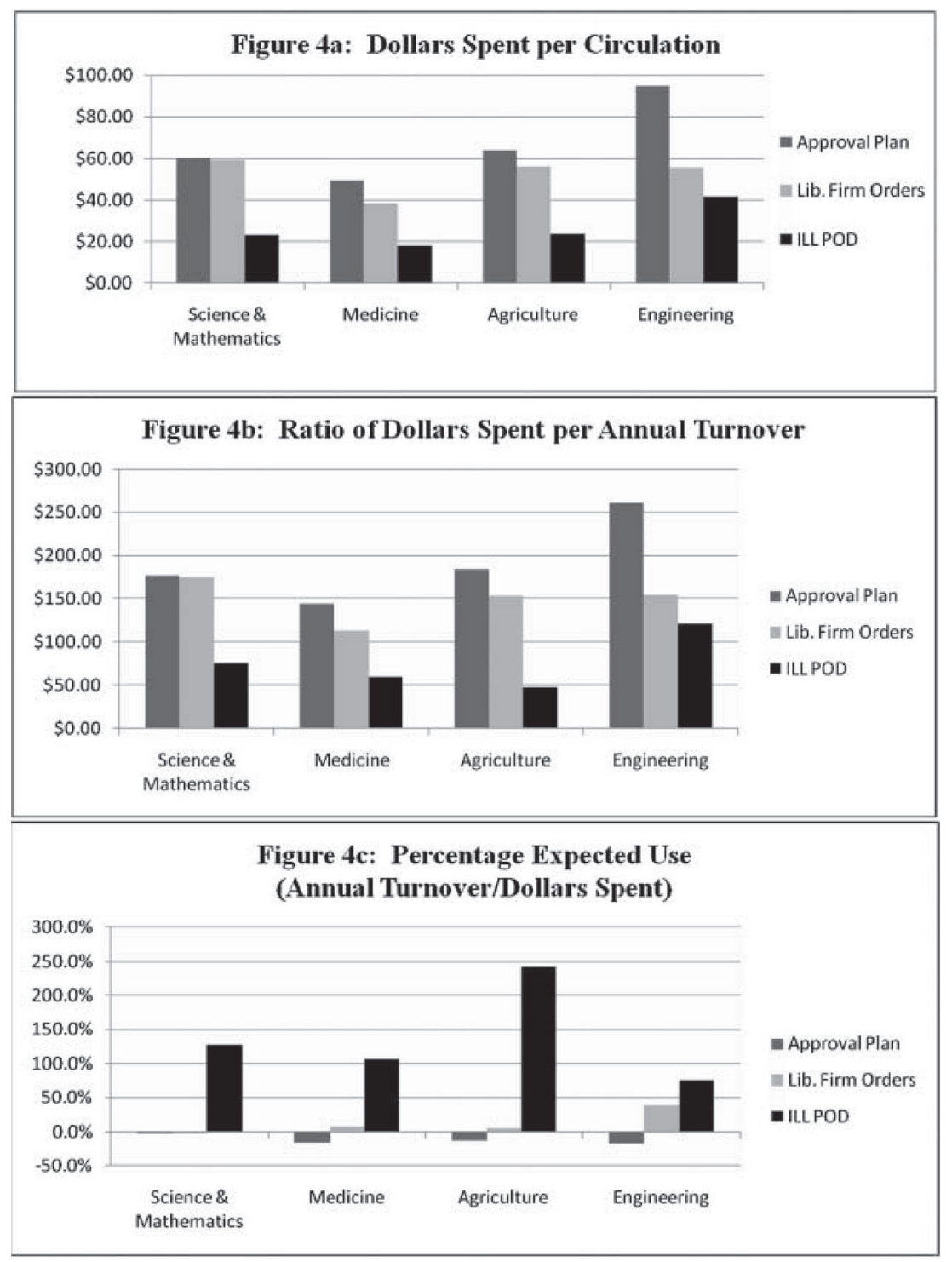

Figure 4. Sciences \& Technology.

Sciences and technology. As Figure 4 shows, in the Sciences \& Technology topical groups, the performance of the three avenues for purchase continued the trend established in the Arts \& Humanities and Social Sciences categories. The ILL POD books performed better in all topical groups and across all indicators. The biggest difference from the results reported above lies in the relationship between the indicators and the average prices paid for the books. Because of the higher prices paid for the Sciences \& Technology books, the dollars spent per circulation for the worst performers from the Approval Plan and the Librarian Firm Orders were roughly equal to the average prices of the books, whereas 
the dollars spent per circulation for the ILL POD books were one half of, or just slightly less than, the average prices of the books (Figure 4a).

Where ratios of dollars spent/annual turnover were concerned, as Figure $4 \mathrm{~b}$ illustrates, the ILL POD books again performed considerably better than did Approval Plan and Librarian Firm Orders. In Science \& Mathematics and in Agriculture, the numerator of the ratio for ILL POD books was less than the average prices of the books, in Medicine it was roughly equal to the average price, and in Engineering it was just 1.5 times higher. In essence, the science patrons who requested the ILL POD books purchased one circulation per year. In contrast, the approval plan book ratios ranged from 2.2 times to 3.1 times the average price (Sciences and Engineering, respectively), and the firm-ordered books' ratios ranged from 1.8 (Engineering) to 2.2 (Sciences and Agriculture) times the average price. The approval plan and the librarians would have had to roughly double or triple the amount of money put into their books in order to match the output generated by the ILL POD books.

This discrepancy in proportional output, again, is clearest in the final graph in Figure 4c. The PEU scores for the ILL POD books in the Sciences \& Technology groupings ranged from $75.7 \%$ (Engineering) to $242.7 \%$ (Agriculture), indicating that the percentage of relative "heat" generated by the ILL POD books was, again, very disproportional to the percentage of "fuel" put into them. ${ }^{5}$

\section{ILL POD Without the "Initial Circulation" Advantage}

Before concluding, it is worthwhile to re-address the frequent objection that ILL POD books are unfairly advantaged by being practically guaranteed at least one circulation upon addition to the collection. To address this issue, the authors subtracted the initial circulation from all of the circulated ILL POD books and repeated their calculations with the modified data for 23 of the 24 topical groups. (Note: Biography had a single ILL POD book with just a single circulation, so no calculations could be performed.) With respect to Dollars Spent per Circulation, ILL POD books still performed better than did Approval Plan books in 19 of the topical groups, with differences in price per circulation ranging from just $\$ 0.52$ to $\$ 31.41$. Approval Plan books performed better than did ILL POD books in just four topical groups, with differences ranging from $\$ 1.15$ to $\$ 11.41$. ILL POD books performed better than Librarian Firm Orders in 17 of the topical groupings, with differences in average price ranging from just $\$ 0.02$ to $\$ 39.92$. Librarian Firm Orders outperformed ILL POD books in six of the topical groups, with differences in performance ranging from $\$ 0.73$ to \$24.54. Results were similar for Ratio of Dollars Spent per Annual Turnover, with ILL POD books outperforming Approval Plan books and Librarian Firm Orders in 19 of the 23 topical groups. What was perhaps most impressive, however, was that, despite losing almost one circulation per book, ILL POD book 
PEU values still indicated that their proportional contribution to the collections' annual turnover rate was greater than the proportion of collection dollars spent on them in 20 of the 23 topical groups. The three exceptions were Home Economics, a topical group with few ILL POD purchases, and Music and Social Sciences \& Statistics, two topical groups with unusually high annual turnover rates for Approval Plan books and for Librarian Firm Orders. It seems that the ILL POD books, even with their initial circulation advantage removed, were exceptionally good additions to the collection. (For a re-graphing of Figures 1-4 with the adjusted data, please see Appendix B).

\section{Conclusions}

The rough conclusions to be drawn from this analysis should be fairly evident. It would appear from the data collected by the UNL University Libraries that ILL POD books did, on average, tend to cost a bit more than did books acquired through traditional avenues, but the authors would argue that this is of little or no import when their circulation performance is taken into account. When compared to ILL POD books, much larger percentages (and much larger actual numbers) of the books acquired through the approval plan, librarian orders, and donor bequests have sat uncirculated on the library shelves, an unfavorable comparison that persists even when one disadvantages the ILL POD books by discounting the initial circulation to the requesting ILL patrons. As a result, the price of a circulation for ILL POD books tends to be lower-much lower in some instances - and the hypothetical price of an annual circulation per book would also be much lower for ILL POD books as well. In almost every instance reviewed, the ILL POD contribution to the UNL Libraries' average rate of circulation was favorably disproportional to the percentage of collection dollars thus spent, even after subtracting their initial circulations. The UNL Libraries' ILL POD books may have cost a bit more, but if one hopes that purchase results in use, then those extra collection dollars would appear to have been very effectively spent.

\section{Limitations to the Study}

The limitations to this study, excluding the aforementioned small amounts of noise in the dataset, are several. First, "circulation" does not exhaustively encompass "use," and "prices paid" does not fully encompass "costs." Unfortunately, the UNL Libraries were not equipped to collect statistics automatically on in-house uses of the books, and the committee that co-initiated the ILL POD program did not, for logistical reasons, require that data on in-house use be collected. Thus, this shortcoming could not be remedied. The same difficulties were true for recording the full costs associated with the acquisition of the books: prices paid were automatically recorded in the books' records, but ship- 
ping and handling charges, staff costs, opportunity costs, and so forth, were not. The library literature suggests that POD program costs may vary significantly. As noted in the literature review, two programs have reported high shipping and handling costs. Many of the programs described in the literature report using online book vendors, such as Amazon, which probably keeps costs low, but other programs report using their book vendor's rush ordering services, which may have added to their POD books' total costs (Clendenning, 2001; Coopey \& Snowman, 2006). With respect to potential staffing costs, some programs report using a librarian with a staff of assistants (Silva \& Weible, 2010), others ask librarians to review and vet potential acquisitions (Gee \& Shirkey, 2010), others report that their programs are run entirely or almost entirely by paraprofessional staff (Anderson et al., 2010; Comer \& Lorenzen, 2006; Tyler et al., 2010), and still others have apparently fully automated their processes (Reynolds et al., 2010). The staffing structure employed by the various programs is likely to affect overall costs. Given the wide differences in performance reported in this study, however, as well as the facts that circulation and price tend to be used more frequently as indicators of use and value, and that spending on collections over the past decade has increased while circulation tallies have decreased (American Library Association, 2009), the authors believe that POD books have a substantial advantage in terms of overall costs and suggest that investing in books with higher-than-average circulation rates is worthwhile, even accounting for some books' having higher (and uncounted) in-house use rates and somewhat higher total costs.

A second shortcoming of the study is that, as a secondary analysis of data automatically collected by the UNL Libraries, it has some characteristics of a onegroup posttest-only or one-shot case study design. As a result, it is difficult to establish definite causal variables and to rule out spurious confounding variables, and the study's generalizability is reduced. Since many similar studies in the library literature have shown that ILL POD books tend to circulate more than do books acquired via traditional channels, the results reported herein could likely be easily and widely replicated elsewhere, and certainly in academic libraries.

Third, the large difference in "sample" sizes among the Approval Plan, Librarian Firm Orders, and ILL POD acquisitions, the small numbers of ILL POD books in several topical groups, the lack of collected data for some likely confounding variables, and the very large number of books with zero circulations makes it difficult to establish with an acceptable level of certainty whether performance differences within the 24 topical groups for the several methods for purchasing books are statistically significant. The differences in performance certainly appear to exist, however, and appear to be sizeable in several instances. To have enough data to be comfortable with making a claim to statistical significance, the authors would have preferred to purchase a much greater number of ILL POD books, which in the current budgetary climate could only have been accomplished by convincing our colleagues to redirect significant 
amounts of money away from the approval plan and firm order budgets and into the ILL POD budget. Needless to say, such plans meet not infrequently with some resistance, given librarians' POD-related worries (Barnhart, 2010; Reynolds et al., 2010). To address this shortcoming of the study, the authors again would make recourse to the near-universality of the higher-than-average use and circulation rates reported elsewhere in the library literature.

Regardless of this particular study's limitations, the library literature of the past decade and more suggests that the study's conclusions are very likely sound, even if they do not offer strict scientific proof. The conclusions should certainly be taken as providing solid support for a practical strategy to ameliorate one of the historical curses of librarianship: the profligate acquisition of materials that see little or no use (Bulick, Sabor, \& Flynn, 1979; Davidson, 1943; Fussler, 1969; Kent et al., 1979; Trueswell, 1969). Libraries that have not yet implemented some sort of patron-driven acquisitions program are likely still spending sizeable percentages of their monograph collection dollars on increasing the dead wood sitting on their shelves.

\section{Notes}

1. As is frequently the case with a study of this sort, the law library was excluded from consideration.

2. The number of LC subclasses reported in an earlier study employing this dataset was 257. This discrepancy, and any other discrepancies between the two studies, was the result of a single ILL POD book that was misclassed as CM rather than CN. In the interval between the two studies, the cataloging staff was able to track down the rogue book and re-class it.

3. Prior to beginning the analysis of relative performance, the authors used SAS to test the distribution of book circulation rates (i.e., their annual turnover rates) for normalcy and then to perform a two-way factorial analysis of the dataset to determine whether, with respect to circulation as expressed via annual turnover rates, there were in the original dataset interaction effects attributable to means of acquisition and to LC subclass. In order to reduce noise effects that could have been caused by LC subclasses that did not have ILL acquisitions, the authors elected to use the subset of LC subclasses with circulated ILL acquisitions (137 subclasses; 66,396 books). The authors would tentatively offer the model constructed to fit the data as follows: Annual Turnover Rate $=$ Acquisition Type + LC Subclass + (Acquisition Type $\times$ LC Subclasses). The model from the two-way factorial experiment was as shown below,

$$
y_{i j k}=\mu+\tau_{i}+\beta_{j}+\gamma_{i j}+\varepsilon_{i j k}
$$

Where: $\mu$ is the overall mean response, $\tau_{i}$ is the effect due to the $i$-th level of factor Acquisition-Type, $\beta_{j}$ is the effect due to the $j$-th level of factor LC Subclass, $\gamma_{i j}$ is the effect due to any interaction between the $i$-th level of Acquisition Type and the $j$-th level of LC Subclass, and $\varepsilon_{i j k}$ is the error which is identically and independently distributed with a zero median (note: LC Subclass had 137 levels; Acquisition Type had five levels).

We tentatively concluded that, with respect to rates of annual turnover, the effect of LC Subclass depends on the level of Acquisition Type and that the interaction effect was significant since the $p$-value for testing the interaction effect was $<.0001$. Thus, it seemed prudent to include only those LC subclasses with ILL POD orders in the performance 
comparisons to follow. However, the authors would offer this model, again, very tentatively, as we feel that we are insufficiently familiar with the technique employed (i.e., a two-way factorial analysis of distribution-free, transformed ranked data from a non-normal dataset which used an alternative to the additive linear model) to know whether it may be novel or sufficiently validated (Sprent \& Smeeton, 2007). In fact, in scanning the literature for examples, we were uncertain as to whether this method even has its own proper name, although something similar does appear to have been advocated by Hettmansperger \& Elmore (2002).

4. What any particular library may deem an "acceptable" value for these ratios is subjective, but for this study, the authors took into account the books' average annual turnover rate ( 1 circulation every 2.38 years) and the fact that a supermajority of the books $(70.4 \%)$ had been available for checkout for at least that long. We concluded that the books in the topical areas should have been checked out at least once, on average. Thus, to be "acceptable," their average book price and their average price paid per circulation should be fairly nearly equal.

5. One might be inclined, at this point, to glance at the values graphed in Figures 2, 3, and 4 and to conclude that Arts \& Humanities, Social Sciences, and Sciences \& Technology all performed roughly similarly. However, the reader ought to keep in mind that the ratios reported were for performance within the topic groups. The ratios may mask differences in performance that result from differences in average price paid within the topic groups, hence the reporting of ratios relative to average price paid in the text. The Sciences \& Technology group's absolute performance (i.e., its price paid per circulation) may appear to be roughly comparable to the Arts \& Humanities group's in several instances, but the performance relative to average prices paid for the books in some Sciences \& Technology topic groups was actually better because the average prices for Sciences \& Technology books were higher. This struck the authors as noteworthy and as a bit of a surprise because the arts and humanities are generally considered more book-oriented and the STEM fields more journal-oriented.

\section{References}

Allen, M., Ward, S. M., Wray, T., \& Debus-López, K. E. (2003). Patron-focused services in three US libraries: Collaborative interlibrary loan, collection development and acquisitions. Interlending \& Document Supply, 31(2), 138-141.

American Library Association. Office for Research \& Statistics. (2009). The condition of U.S. libraries: Academic library trends, 1999-2009. The Association. Retrieved from http://www. ala.org/ala/research/librarystats/academic/Condition_of_Libraries_1999.20.pdf

Anderson, K. J., Freeman, R. S., Hérubel, J. V. M., Mykytiuk, L. J., Nixon, J. M., \& Ward, S. M. (2002). Buy, don't borrow: Bibliographers' analysis of academic library collection development through interlibrary loan requests. Collection Management, 27(3/4), 1-10.

Anderson, K. J., Freeman, R. S., Hérubel, J. V. M., Mykytiuk, L. J., Nixon, J. M., \& Ward, S. M. (2010). Liberal arts books on demand: A decade of patron-driven collection development, part I. Collection Management, 35(3/4), 125-141.

Baker, S. L., \& Wallace, K. L. (2002). The responsive public library: How to develop and market a winning collection (2nd ed.). Englewood, CO: Libraries Unlimited.

Barnhart, A. C. (2010). Want buy-in? Let your students do the buying! A case study of course-integrated collection development. Collection Management, 35(3/4), 237-243. 
Bertuca, C., Lelonek, C., Tuohy, R., Ortner, J., Bouvier, A., Dithomas, S., et al. (2009). Two ILLiad clients, one desktop, purchase on demand: Sharing a university's collection, staff, and expertise. Journal of Access Services, 6(4), 497-512.

Bombeld, M., \& Hanerfeld, A. (2004, April). The surprising truth about faculty perception and use of collection development opportunities: One library's case study. Against the Grain, 16, 18-22.

Brug, S., \& MacWaters, C. (2004, Fall). Patron-driven purchasing from interlibrary loan requests. Colorado Libraries, 30, 36-38.

Bulick, S., Sabor, W. N., \& Flynn, R. (1979). Circulation and in-house use of books. In A. Kent, et al. (Eds.), Use of library materials: The University of Pittsburgh study (pp. 9-55). New York, NY: Marcel Dekker.

Campbell, S. A. (2006). To buy or to borrow, that is the question. Journal of Interlibrary Loan, Document Delivery \& Electronic Reserve, 16(3), 35-39.

Carlisle Fountain, K., \& Frederiksen, L. (2010). Just passing through: Patron-initiated collection development in Northwest academic libraries. Collection Management, 35(3/4), 185-195.

Chan, G. R. Y. C. (2004). Purchase instead of borrow: An international perspective. Journal of Interlibrary Loan, Document Delivery E Information Supply, 14(4), 23-37.

Clendenning, L. F. (2001, January). Purchase express for any user request. College $\mathcal{E}$ Research Libraries News, 62, 16-17.

Cohen, J. (1979). The economics of materials' use. In A. Kent, \& et al. (Eds.), Use of library materials: The University of Pittsburgh study (pp. 105-159). New York, NY: Marcel Dekker.

Comer, A., \& Lorenzen, E. (2006). Is purchase on demand a worthy model? Do patrons really know what they want? In Charleston Conference Proceedings (26th), 2006 (pp. 171179). Charleston, South Carolina.

Coopey, B. M., \& Snowman, A. M. (2006, February). ATG special report-ILL purchase express. Against the Grain, 18, 46-49.

Cornell University Library. (2007). Buy or borrow. Retrieved from http://ecommons.cornell.edu/bitstream/1813/12349/1/COL 2007-03-07Buy or Borrow.pdf

Davidson, J. S. (1943). The use of books in a college library. College $\mathcal{E}$ Research Libraries, 4(3), 294-297.

Foss, M. (2007). Books-on-demand pilot program: An innovative "patron-centric" approach to enhance the library collection. Journal of Access Services, 5(1), 306-315.

Fussler, H. H., \& Simon, J. L. (1969). Patterns in the use of books in large research libraries. Chicago: The University of Chicago Press.

Gee, W., \& Shirkey, C. (2010). Giving patrons what they want: An analysis of a thesis and dissertation purchase-on-demand project at East Carolina University. Journal of Interlibrary Loan, Document Delivery \& Electronic Reserve, 20(2), 103-114.

Gibson, T. M., \& Kirkwood, P. E. (2009). A purchase-on-demand pilot project at the University of Arkansas for the Proceedings of the Materials Research Society Symposiums. Journal of Interlibrary Loan, Document Delivery \& Electronic Reserve, 19(1), 47-56.

Hettmansperger, T. P., \& Elmore, R. (2002). Tests for interaction in a two-way layout: Should they be included in a nonparametrics course? Paper presented at the ICOTS 6, South Africa. Retrieved from http://www.stat.auckland.ac.nz/ iase/ publications $/ 1 / 3 g 4$ _hett.pdf 
Hodges, D., Preston, C., \& Hamilton, M. J. (2010). Patron-initiated collection development: Progress of a paradigm shift. Collection Management, 35(3/4), 208-221.

Houle, L. (2003). Convergence between interlibrary loan and acquisitions: Can it be done? Paper presented at the 8th Interlending \& Document Supply International (ILDS) Conference, National Library of Australia in Canberra, Australia. Retrieved from http:// www.nla.gov.au/ilds/abstracts/HouleL.pdf

Houle, L. (2004). Convergence between interlibrary loan and acquisitions: A science and engineering library experience. Paper presented at the Library Management in Changing Environment: Proceedings of the 25th Annual IATUL Conference, The Library of Cracow University of Technology, Kraków, Poland. Retrieved from http://www.iatul. org/doclibrary/public/Conf Proceedings/ 2004/Louis20Houle.pdf

Hussong-Christian, U., \& Goergen-Doll, K. (2010a). Buy request: Just in time v. just in case at OSU libraries. Paper presented at the 2010 Acquisitions Institute at Timberline Lodge, Timberline Lodge, OR. May 15-18. Retrieved from http://ir.library.oregonstate.edu/jspui/handle/1957/16091

Hussong-Christian, U., \& Goergen-Doll, K. (2010b). We're listening: Using patron feedback to assess and enhance purchase on demand. Journal of Interlibrary Loan, Document Delivery \& Electronic Reserve, 20(5), 319-335.

Ingold, J. L. (2004, 04). Buyer beware: Using interlibrary loan requests in purchasing decisions. Against the Grain, 16, 30-34.

Jackson, M. E. (1989, December). Library to library. Wilson Library Bulletin, 64, 88-89.

Kent, A. et al. (Eds.). (1979). Use of library materials: The University of Pittsburgh Study. New York, NY: Marcel Dekker.

Kuhn, M. S. (2004, April). The intersection where collection development and acquisitions meet interlibrary loan. Against the Grain, 16, 28-30.

Levine-Clark, M. (2010). Developing a multiformat demand-driven acquisition model. Collection Management, 35(3/4), 201-207.

Mills, T. R. (1982). The University of Illinois film center collection use study (unpublished CAS Paper). Urbana, IL: University of Illinois.

Nixon, J. M., \& Saunders, E. S. (2010). A study of circulation statistics of books on demand: A decade of patron-driven collection development, part 3. Collection Management, 35(3/4), 151-161.

Perdue, J., \& Van Fleet, J. (1999). Borrow or buy? Cost-effective delivery of monographs. Journal of Interlibrary Loan, Document Delivery E Information Supply, 9(4), 19-28.

Price, J., \& McDonald, J. (2009). Beguiled by bananas: A retrospective study of the usage \& breadth of patron vs. librarian acquired ebook collections. Paper presented at the e-Book Acquisition at Academic Libraries symposium, XXIX Annual Charleston Conference: Issues in Book and Serial Acquisition, Retrieved from http://ccdl.libraries.claremont.edu/

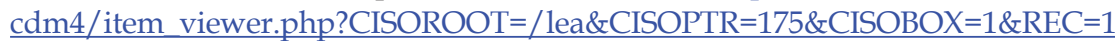

Reynolds, L. J., Pickett, C., Vanduinkerken, W., Smith, J., Harrell, J., \& Tucker, S. (2010). User-driven acquisitions: Allowing patron requests to drive collection development in an academic library. Collection Management, 35(3/4), 244-254.

Rottmann, F. K. (1991). To buy or to borrow: Studies of the impact of interlibrary loan on collection development in the academic library. Journal of Interlibrary Loan $\mathcal{E}$ Information Supply, 1(3), 17-27. 
Ruppel, M. (2006). Tying collection development's loose ends with interlibrary loan. Collection Building, 25(3), 72-77.

Silva, E. S., \& Weible, C. L. (2010). Own not loan: Different request sources for purchase lists. Collection Management, 35(3/4), 180-184.

Sprent, P., \& Smeeton, N. C. (Eds.). (2007). Applied nonparametric statistical methods (4th ed.). Boca Raton, LA: Chapman \& Hall/CRC.

Stowell Bracke, M. (2010). Science and technology books on demand: A decade of patrondriven collection development, part 2. Collection Management, 35(3/4), 142-150.

Trueswell, R. L. (1969). Some behavioral patterns of library users: The 80/20 rule. Wilson Library Bulletin, 43(5), 458-461.

Tyler, D. C., Xu, Y., Melvin, J. C., Epp, M., \& Kreps, A. M. (2010). Just how right are the customers?: An analysis of the relative performance of patron-initiated interlibrary loan monograph purchases. Collection Management, 35(3/4), 162-179. doi: 10.1080/01462679.2010.487030

University of Nebraska-Lincoln Libraries. (2009a). UNL | Libraries | About | Dean's Welcome. Retrieved from http://libraries.unl.edu/about

University of Nebraska-Lincoln Libraries. (2009b). UNL | Libraries | Assessment | Statistics. Retrieved from http:/ /libraries.unl.edu/assessmentstats

University of Nebraska-Lincoln, Office of Institutional Research and Planning. (20052009). University of Nebraska-Lincoln fact book. Lincoln, NE. Retrieved from http://irp. unl.edu/factbooks.html

Ward, S. M. (2002). Books on demand: Just-in-time acquisitions. The Acquisitions Librarian, 14(27), 95-107.

Ward, S. M., Wray, T., \& Debus-López, K. E. (2003). Collection development based on patron requests: Collaboration between interlibrary loan and acquisitions. Library Collections, Acquisitions, \& Technical Services, 27(2), 203-213.

Way, D. (2009). The assessment of patron-initiated collection development via interlibrary loan at a comprehensive university. Journal of Interlibrary Loan, Document Delivery $\mathcal{E}$ Electronic Reserve, 19(4), 299-308.

Zopfi-Jordan, D. (2008). Purchasing or borrowing: Making interlibrary loan decisions that enhance patron satisfaction. Journal of Interlibrary Loan, Document Delivery \& Electronic Reserve, 18(3), 387-394. 


\section{Appendix A}

Categories, Topic Groups, and Library of Congress Subclasses

\begin{tabular}{|c|c|c|}
\hline Categories & Topic Group & Library of Congress Subclasses* \\
\hline \multirow{3}{*}{$\begin{array}{l}\text { General Literature, } \\
\text { Biography, and LIS }\end{array}$} & General Literature & AC, AE, AG, AM, AS, AZ $(2, \$ 186.41)$ \\
\hline & Biography & CT $(1, \$ 23.76)$ \\
\hline & LIS & Z (16, \$1,031.47), ZA (2; \$137.57) \\
\hline \multirow[t]{6}{*}{ Arts \& Humanities } & Philosophy & $\begin{array}{l}\text { B }(22, \$ 1,163.36), \text { BC }(2, \$ 179.47) \\
\text { BD }(5, \$ 243.99), \text { BH }(1, \$ 44.88) \\
\text { BJ }(14, \$ 594.28)\end{array}$ \\
\hline & Religious Studies & $\begin{array}{c}\text { BL }(11, \$ 533.52), \text { BM }(8, \$ 368.60) \\
\text { BP }(3, \$ 59.89), \text { BQ, BR }(15, \$ 812.24) \\
\text { BS }(9, \$ 326.72), \text { BT }(11, \$ 604.71) \\
\text { BV }(2, \$ 55.47), \text { BX }(12, \$ 591.62)\end{array}$ \\
\hline & History & $\begin{array}{l}\text { CB }(3, \$ 141.27), C C(2, \$ 222.40), C D, \\
\text { CE, CJ, CN (1, \$92.04), CR, CS, } \\
\text { D (21, \$718.05), DA (8, \$434.34), } \\
\text { DAW, DB, DC (2, \$39.28), DD (1, } \\
\text { \$19.94), DE, DF (1, \$29.99), DG (5, } \\
\text { \$252.71), DH, DJ, DJK (2, \$111.43), } \\
\text { DK (2, \$94.12), DL, DP, DQ, DR (2, } \\
\text { \$149.95), DS (14, \$838.63), DT (7, } \\
\text { \$329.20), DU (3, \$248.40), DX, } \\
\text { E (53, \$2,189.93), F (39, \$1,333.61) }\end{array}$ \\
\hline & Music & $\begin{array}{l}\text { M (1, \$13.47), ML }(20, \$ 1,108.32) \\
\quad \text { MT }(2, \$ 118.18)\end{array}$ \\
\hline & $\begin{array}{l}\text { Art, Architecture, } \\
\text { \& Photography** }\end{array}$ & $\begin{array}{l}\text { N }(32, \$ 1,814.85), \text { NA }(37, \$ 1,726.05) \\
\text { NB }(2, \$ 258.72), \text { NC }(8, \$ 426.90) \\
\text { ND }(20, \$ 970.97), \text { NE, NK }(5, \$ 265.70) \\
\text { NX }(3, \$ 119.98), \text { TR }(19, \$ 720.08)\end{array}$ \\
\hline & $\begin{array}{l}\text { Languages \& } \\
\text { Literature*** }\end{array}$ & $\begin{array}{l}\text { P }(25, \$ 1,330.46), \text { PA }(3, \$ 144.06), \text { PB, } \\
\text { PC, PD, PE (9, \$312.77), PF, PG, PH, } \\
\text { PJ }(1, \$ 141.99), \text { PK, PL }(2, \$ 251.37), \\
\text { PM, PN }(40, \$ 1,549.69), \text { PQ }(11, \$ 707.18), \\
\text { PR }(50, \$ 2,752.42), \text { PS }(23, \$ 940.40) \\
\text { PT }(1, \$ 87.49)\end{array}$ \\
\hline \multirow[t]{6}{*}{ Social Sciences } & Psychology & BF $(46, \$ 2,801.90)$ \\
\hline & $\begin{array}{l}\text { Geography \& } \\
\text { Environment }\end{array}$ & $\begin{array}{l}\text { G }(6, \$ 326.07), \text { GA, GB }(1, \$ 68.82) \\
\text { GC }(1, \$ 213.03), \text { GE }(1, \$ 25.25) \\
\text { GF }(5, \$ 283.11)\end{array}$ \\
\hline & $\begin{array}{l}\text { Anthropology \& } \\
\text { Leisure Studies }\end{array}$ & $\begin{array}{l}\text { GN }(14, \$ 626.25), \text { GR, GT }(6, \$ 335.90) \\
\text { GV }(4, \$ 260.18)\end{array}$ \\
\hline & $\begin{array}{l}\text { Social Sciences \& } \\
\text { Statistics }\end{array}$ & H $(6, \$ 379.16), \mathbf{H A}(3, \$ 214.06)$ \\
\hline & Business \& Economics & $\begin{array}{l}\text { HB }(4, \$ 132.45), \text { HC }(13, \$ 693.67) \\
\text { HD }(50, \$ 2,583.06), \text { HE }(4, \$ 277.15) \\
\text { HF }(26, \$ 1,264.96), \text { HG }(9, \$ 750.24) \\
\text { HJ }\end{array}$ \\
\hline & Sociology & $\begin{array}{l}\text { HM }(44, \$ 2,623.59), \text { HN }(8, \$ 363.99) \\
\text { HQ }(47, \$ 2,254.01), \text { HS }(1, \$ 21.27) \\
\text { HT }(9, \$ 392.25), \text { HV }(38, \$ 1,982.87) \\
\text { HX }(5, \$ 122.24)\end{array}$ \\
\hline
\end{tabular}


Categories, Topic Groups, and Library of Congress Subclasses (Continued)

\begin{tabular}{|c|c|c|}
\hline Categories & Topic Group & Library of Congress Subclasses* \\
\hline & Political Science & $\begin{array}{c}\text { J, JA }(1, \$ 80.75), \text { JC }(11, \$ 407.05), \\
\text { JF }(3, \$ 175.96), \text { JJ, JK }(3, \$ 128.900, \text { JL, } \\
\text { JN }(6, \$ 280.44), \text { JQ }(4, \$ 108.75), \text { JS, } \\
\text { JV }(7, \$ 412.75), \text { JX, JZ }(10, \$ 441.04)\end{array}$ \\
\hline & Law & $\begin{array}{l}\text { K (15, \$973.08), KB (1, \$27.02), KBM, } \\
\text { KBP, KBR, KD, KF (8, \$416.18), KFA, } \\
\text { KFC, KFF, KFH, KFI, KFM, KFN, KFO, } \\
\text { KFP, KFV, KFX, KG (1, \$74.22), KGF, } \\
\text { KH, KJ, KJA, KJC, KJE (1, \$137.75), } \\
\text { KJP, KJV, KJW, KK (2, \$239.96), KKH, } \\
\text { KKJ, KKZ, KL, KLA, KLB, KMC, KMH, } \\
\text { KMK, KMM, KMQ, KNC, KNM, KNN, } \\
\text { KNQ (1, \$32.67), KNR, KNS (1, \$54.24), } \\
\text { KNX, KPH, KPL, KPM, KQ, } \\
\text { KQC (1, \$59.32), KSK, KTA, KTL, } \\
\text { KTW, KU, KZ (13, \$786.90) }\end{array}$ \\
\hline & Education & $\begin{array}{l}\text { L, LA, LB }(33, \$ 1,653.35) \\
\text { LC }(12, \$ 384.13), \text { LD }(1, \$ 34.33), \text { LF, } \\
\text { LG, LJ }(1, \$ 42.93)\end{array}$ \\
\hline & Home Economics & TT $(1, \$ 56.25), \mathrm{TX}$ \\
\hline & $\begin{array}{l}\text { Military \& Naval } \\
\text { Science }\end{array}$ & $\begin{array}{l}\text { U }(3, \$ 113.84), \mathrm{UA}, \mathrm{UB}, \mathrm{UC}, \mathrm{UD}, \mathrm{UF}, \\
\mathrm{UG}(2, \$ 73.19), \mathrm{UH}, \mathrm{V}, \mathrm{VA}, \mathrm{VB}, \mathrm{VE} \\
\text { VG, VK, VM }\end{array}$ \\
\hline \multirow[t]{4}{*}{ Sciences \& Technology } & Science \& Mathematics & $\begin{array}{l}\text { Q }(3, \$ 213.33), \mathrm{QA}(56, \$ 3,740.20), \\
\text { QB }(1, \$ 70.72), \mathrm{QC}(18, \$ 2,334.67) \\
\text { QD }(13, \$ 1,730.51), \mathrm{QE}(2, \$ 158.43) \\
\text { QH }(24, \$ 1,526.55), \mathrm{QK}(6, \$ 514.92) \\
\text { QL }(4, \$ 259.00), \mathrm{QM}(1, \$ 15.46) \\
\text { QP }(15, \$ 1,255.95), \mathrm{QR}(5, \$ 546.52)\end{array}$ \\
\hline & Medicine & $\begin{array}{l}\text { R }(19, \$ 910.89), \text { RA }(20, \$ 1,272.30) \\
\text { RB }(1, \$ 172.95), \text { RC }(53, \$ 3,537.70) \\
\text { RD }(3, \$ 69.14), \text { RE, RF }(1, \$ 191.60) \\
\text { RG }(5, \$ 310.93), \text { RJ }(19, \$ 868.95) \\
\text { RK }(1, \$ 59.70), \text { RL, RM }(1, \$ 166.43) \\
\text { RS }(2, \$ 315.33), \text { RT, RX, RZ }\end{array}$ \\
\hline & Agriculture & $\begin{array}{l}\text { S, SB }(6, \$ 366.79), \text { SD, SF }(4, \$ 340.67) \text {, } \\
\text { SH, SK }\end{array}$ \\
\hline & Engineering & $\begin{array}{l}\text { T }(5, \$ 308.12), \text { TA }(14, \$ 1,752.88), \\
\text { TC }(2, \$ 179.73), \text { TD }(1, \$ 126.40), \text { TE, } \\
\text { TF, TG, TH }(1, \$ 26.68), \text { TJ }(3, \$ 479.18) \\
\text { TK }(13, \$ 1,529.48), \text { TL }(1, \$ 35.57), \\
\text { TN }(1, \$ 61.70), \text { TP }(11, \$ 1,445.84) \\
\text { TS }(7, \$ 567.55)\end{array}$ \\
\hline
\end{tabular}

* LC Subclasses listed experienced acquisitions during the interval; LC Subclasses in bold had ILL POD acquisitions; numbers following in parentheses indicate the number of books purchased and dollars spent via ILL POD.

** Note: Architecture (NA) is traditionally grouped with the social sciences at the UNL University Libraries, but the authors have placed it in this topic group as it seemed a more appropriate fit.

*** Note: Fiction and juvenile belles letters (PZ), which is traditionally grouped with the social sciences at the UNL University Libraries because books in this subclass are generally purchased for the education program, was not included in the comparisons because it was blocked by the ILL POD program's governing criteria. 


\section{Appendix B: Figures With ILL POD Initial Circulation Adjusted}
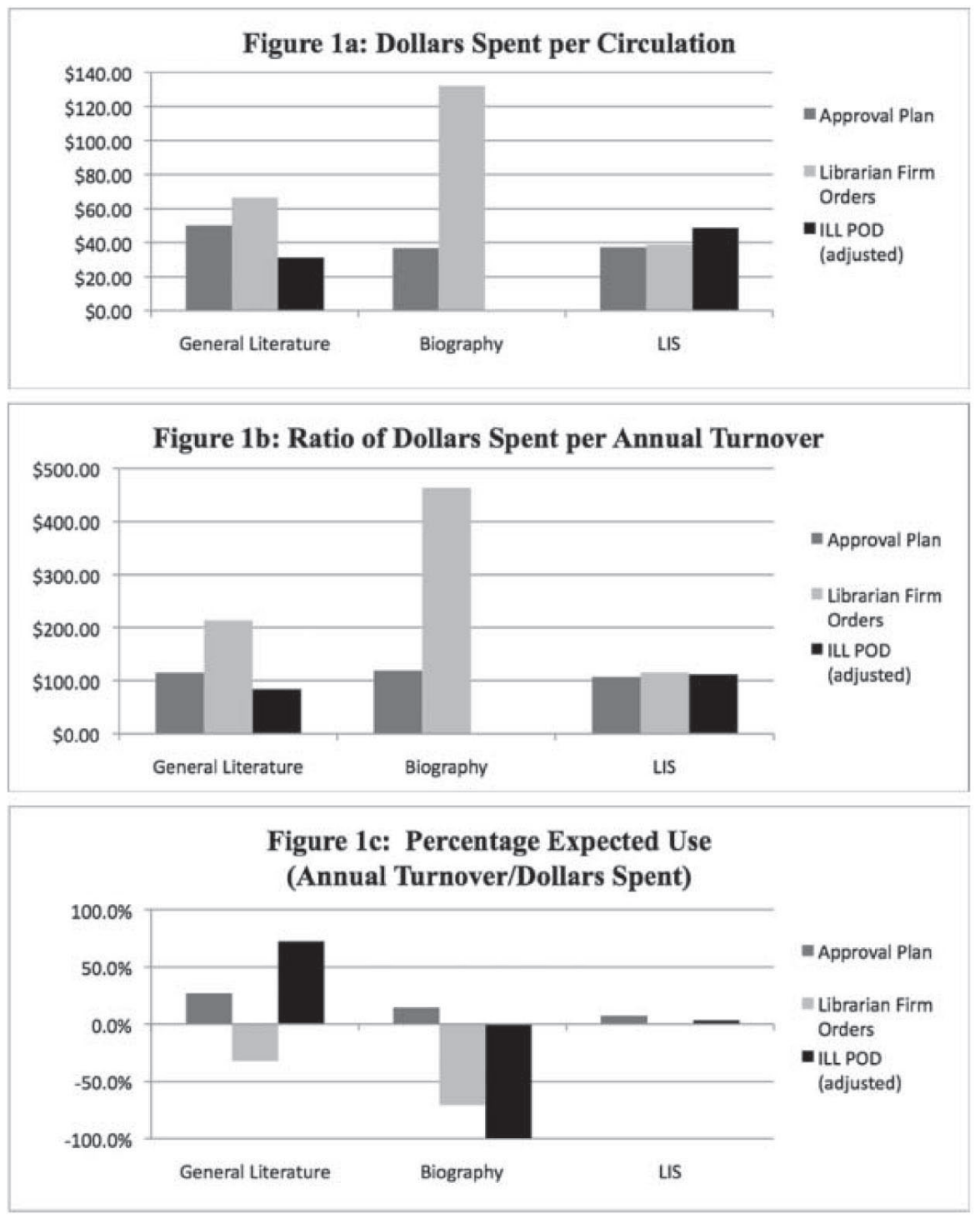

Figure 1. (adjusted) General Literature, Biography, and LIS. 

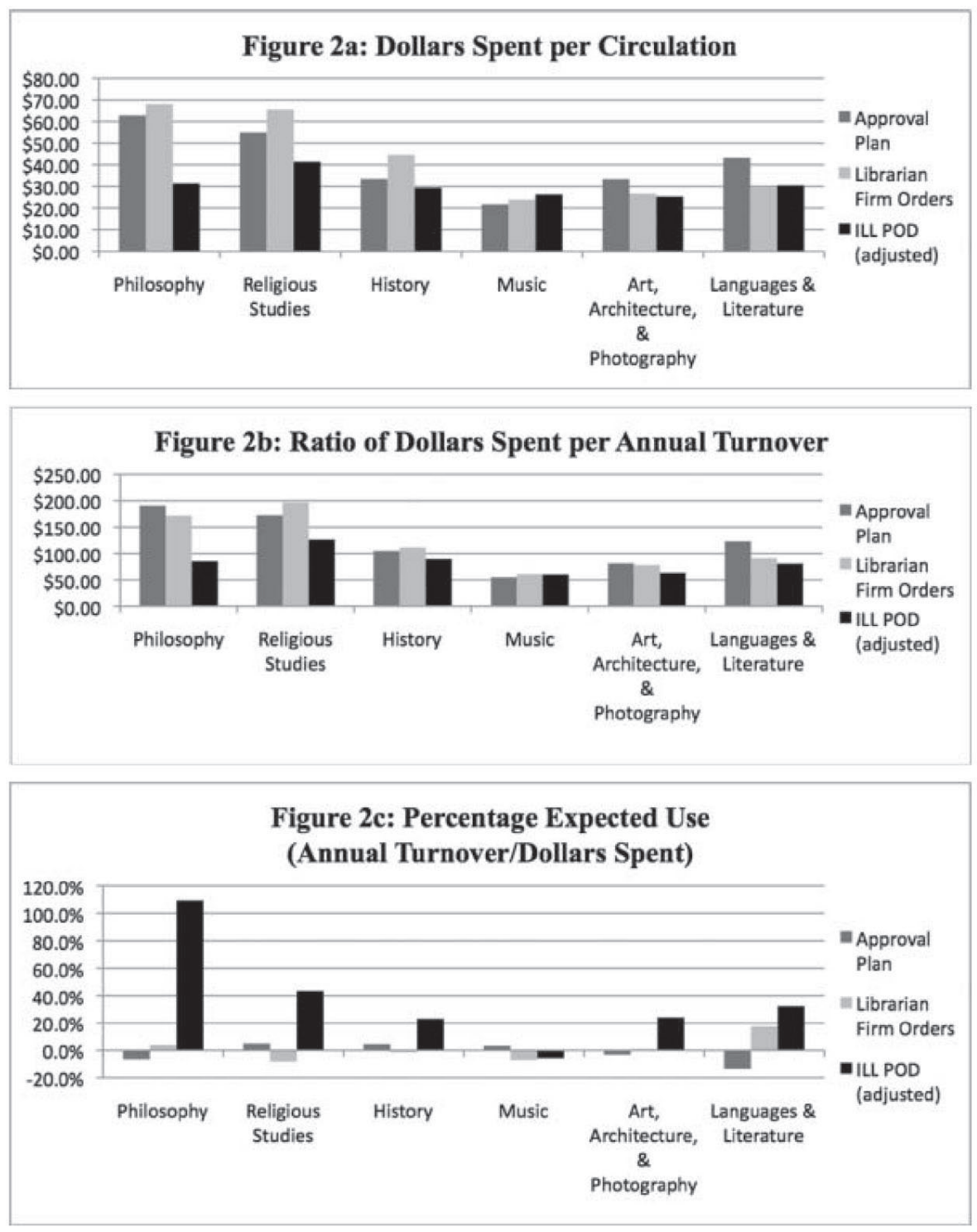

Figure 2. (adjusted) Arts and Humanities. 

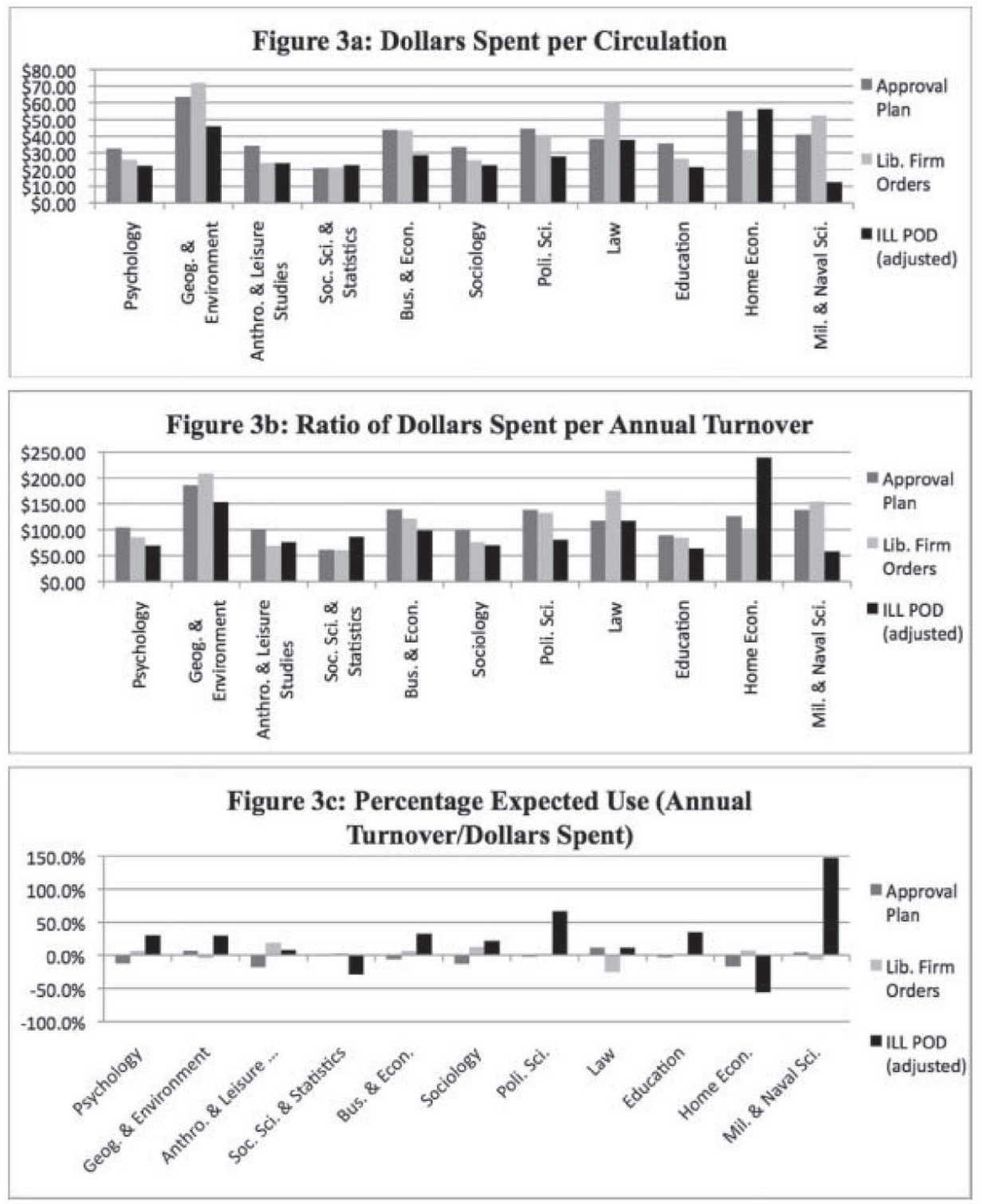

Figure 3. (adjusted): Social Sciences. 

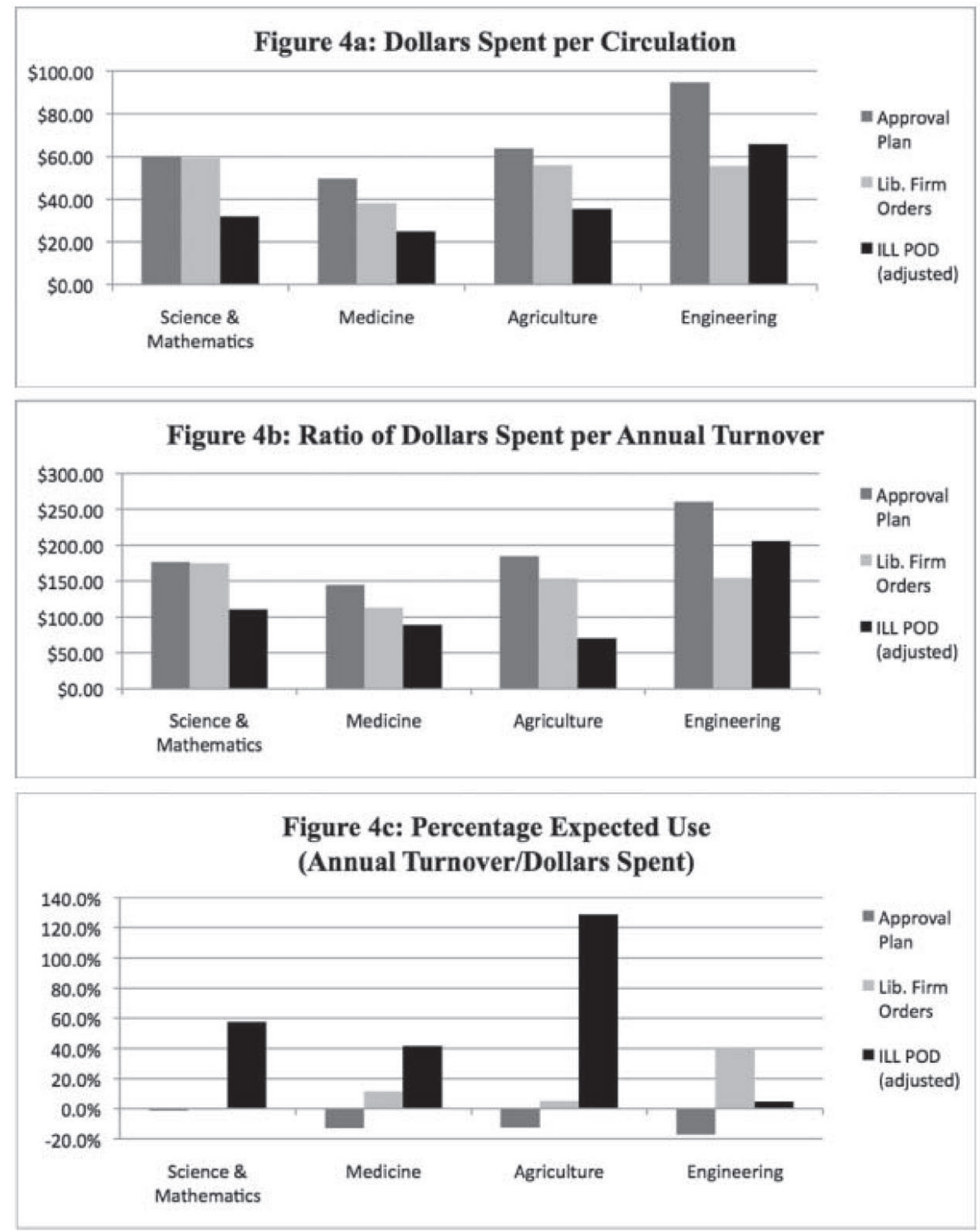

Figure 4. (adjusted) Sciences and Technology. 


\section{Appendix C: UNL University Libraries' ILL Purchasing Project Criteria (2010-11)}

All books requested via ILLiad, published between 2007-10 and not owned by UNL Libraries must be considered for purchase (books in IRIS that are counted as missing, lost, or on search cannot be purchased). Selected books will be judged by the following criteria. Books must be available from Barnes and Noble online and must arrive in a timely manner. We cannot order any book that takes longer than 2-3 days to ship. We also cannot order books that are marked as "Pre-orders." The price limit on purchasing project books is $\$ 175$; we may not order books that cost more than this amount. Books purchased have academic merit. The following type of books may not be purchased.

- Textbooks (any book designated by OCLC or Barnes \& Noble as a textbook)

- Foreign language books

- Fiction

- Poetry

- Plays

- Music Scores

- Lab manuals

- Workbooks

- Field guides

- Solutions manuals

- Popular interest (non-fiction, best sellers, self-help, etc.)

- Popular biographies (biographies can be decided on a case-by-case basis)

- Journal volumes/serials

- Computer books

- Anthologies

- Older editions of a book that still fall within the 3-year period

Most books not marked as textbooks published by university presses are appropriate for the ILL purchasing program. Another way to judge a book which may be published by an unknown publisher but is not disqualified by any of the above criteria is to look in the OCLC holdings to see which other libraries own this item. If it is owned by many GWLA and ARL libraries, it should be purchased. If it is owned by mostly public libraries, it should be obtained via interlibrary loan. If it is a new book not owned by many libraries or you think it would be a good addition to the collection, decide which subject area the book falls under and consult the library liaison. Ask if they feel the book is a worthwhile purchase. If they feel that it is, you may buy it. If the liaison is not available or the book falls under the prohibited categories but still seems like a good addition to the library collection, ask [the Chair of Technical Services] for permission to purchase it. 